\title{
HEAT OR EAT? COLD WEATHER SHOCKS AND NUTRITION IN POOR AMERICAN FAMILIES
}

\author{
Jayanta Bhattacharya \\ Thomas DeLeire \\ Steven Haider \\ Janet Currie \\ Working Paper 9004 \\ http://www.nber.org/papers/w9004
NATIONAL BUREAU OF ECONOMIC RESEARCH 1050 Massachusetts Avenue
Cambridge, MA 02138
June 2002

We thank the Joint Center for Poverty Research and the Institute for Research on Poverty for financial support of this project. Seminar participants at Northwestern University, University of Chicago, University of Wisconsin, the National Bureau of Economic Research at Stanford University, the Midwestern Economics Association, and the Western Economics Association provided helpful feedback and suggestions. We thank Alison Jacknowitz and William Clune for expert research assistance. The views expressed herein are those of the authors and not necessarily those of the National Bureau of Economic Research.

(C) 2002 by Jayanta Bhattacharya, Thomas DeLeire, Steven Haider and Janet Currie. All rights reserved. Short sections of text, not to exceed two paragraphs, may be quoted without explicit permission provided that full credit, including (C) notice, is given to the source. 
Heat or Eat? Cold Weather Shocks and Nutrition in Poor American Families

Jayanta Bhattacharya, Thomas DeLeire, Steven Haider and Janet Currie

NBER Working Paper No. 9004

June 2002

JEL No. I32, I12

\begin{abstract}
We examine the effects of cold weather periods on family budgets and on nutritional outcomes in poor American families. Expenditures on food and home fuels are tracked by linking the Consumer Expenditure Survey to temperature data. Using the Third National Health and Nutrition Examination Survey, we track calorie consumption, dietary quality, vitamin deficiencies, and anemia in summer and winter months. We find that both rich and poor families increase fuel expenditures in response to unusually cold weather (a $10^{\circ} \mathrm{F}$ drop below normal). At same time, poor families reduce food expenditures by roughly the same amount as the increase in fuel expenditures, while rich families increase food expenditures. Poor adults and children reduce caloric intake by roughly 200 calories during winter months, unlike richer adults and children. In sensitivity analyses, we find that decreases in food expenditure are most pronounced outside the South. We conclude that poor parents and their children outside the South spend and eat less food during cold weather temperature shocks. We surmise that existing social programs fail to buffer against these shocks.
\end{abstract}

Jayanta Bhattacharya

Stanford University School of Medicine

Center for Primary Care Outcomes Research

Center for Health Policy

218 Encina Commons

Stanford, CA 94305-6019

jay@stanford.edu

Steven Haider

RAND

1700 Main Street

Santa Monica, CA 90401

sjhaider@rand.org
Thomas DeLeire

Harris Graduate School of Public Policy Studies

University of Chicago

1155 E. 60th St.

Chicago, IL 60637

t-deleire@uchicago.edu

Janet Currie

UCLA

405 Hilgard Avenue

Los Angeles, CA 90095-1477

and NBER

currie@simba.sscnet.ucla.edu 


\section{Introduction}

In many parts of the country, American winters can impose a financial burden on families. Newspaper reports suggest that poor families with children, who are often least able to cope with such budgetary pressures, are hit the hardest. These families can face difficult decisions about where to place their resources, deciding between heating their homes, feeding themselves, or feeding their children. For example, the New York Times, 26 February 2001, reported that parents reduce their use of utilities to pay for food. One family member interviewed reported that "[w]e owe $\$ 800$ on the water bill and $\$ 500$ for heat." The outcomes of these tough choices may have a large impact on the nutritional well being of children. Some of the harm will be tempered if parents can shield their children from nutritional deprivation. The same newspaper article also reported that some poor parents "routinely go without dinner to make sure their...children have enough to eat."

The purpose of this paper is to investigate whether poor American families have lower food expenditures and worse nutritional outcomes during cold-weather periods and to determine the extent to which parents protect their children from these shocks. We use two large and nationally representative data sets. The first, the Consumer Expenditure Survey (CEX), collected by the U.S. Bureau of Labor Statistics (BLS), has extensive information about food and other expenditures by American families over a long time period. The second, the Third National Health and Nutrition Examination Survey (NHANES III), is the gold standard for nationally representative nutritional data.

We find that both rich and poor families increase fuel expenditures in response to unusually cold weather. However, poor families respond to these shocks by reducing food expenditures while rich families increase food expenditures. Poor adults and children reduce caloric intake by $10 \%$ during the winter months, whereas rich families do not reduce their caloric intake during the winter. These findings suggest that existing social programs do not buffer against shocks to family budgets caused by unusual weather. 


\section{Background}

Frank starvation is rare in the U.S. However, poor nutritional choices ("misnutrition") are rampant. American children are at risk of having diets that are high in fat, high in sweets, and low in fruit and vegetables. (Bhattacharya and Currie, 2001). There are few studies that find vitamin intake deficiencies in American children (see Devaney et al. 1995 and Middleman et al. 1996). However, Bhattacharya and Currie find a high prevalence of anemia, high blood cholesterol, and some evidence of serum vitamin deficiencies among American adolescents.

While low serum vitamin levels are clinically difficult to evaluate in the context of a single patient, they are good measures of dietary inadequacy in broad populations. The relationship between micronutrient intake and blood levels of these nutrients is complicated. Because the body can store some vitamins and minerals for a long time, it is not anomalous to find a respondent who has not recently consumed the recommended amount of some vitamin and yet does not have a deficiency in that vitamin according to blood tests. For example, it can take between three to six years for a deficiency in vitamin $B_{12}$ to become clinically evident (Middleman et al. 1996). Nevertheless, blood tests can provide solid objective evidence of micronutrient malnutrition, when properly interpreted.

Though poor diets seldom result in classic vitamin deficiency related to diseases like scurvy or pellagra, low vitamin and mineral levels could have long-term health consequences. For example, even mild iron deficiency is associated with fatigue, shortened attention span, decreased work capacity, reduced resistance to infection, and impaired intellectual performance (U.S. CDC 1996).

There are recent studies in the public health literature that are concerned with whether poor children receive inadequate diets during winter. Frank et al. (1996) report that the fraction of emergency room visits by small-for-age children rises during the winter months in a Boston hospital. However, relying on British data, Lawlor et al. (2000) and Shah and Peacock (1999) fail to identify any relation between excess winter mortality and deprivation.

American economists have examined nutritional resource sharing in poor families. Wilde (1997) and Wilde and Ranney (1997) examine whether poor families on 
food stamps eat less towards the end of a benefit month. Adults frequently eat less during the fourth week while children have smooth food consumption throughout the month. These findings suggest that the food consumption of poor families is potentially vulnerable to financial strains but that parents in poor families are able to protect their children from the adverse effects of these strains to some extent.

\section{Methods}

\section{Sample and Procedures}

In this study, we use two complementary datasets. To measure patterns of expenditure on food and on home fuel, we use data from the 1980 though 1998 interview surveys of the CEX. Each household reports up to 12 months of consumption data as well as demographic, geographic, and income information. The CEX collects expenditure data at the household level from roughly 5,000 families each month, so our ultimate sample contains 104,747 households, 35,509 of which have children under the age of 18 in the household. Survey weights are provided so that the CEX sample is nationally representative within any given month. From the National Oceanic and Atmospheric Administration, we obtain data on mean ground temperature for each state in each month between 1980 and 1998. We merge these data with the CEX using information on each family's state of residence. With this large sample of households, we can examine the differential changes in spending patterns at the household level. However, the CEX cannot be used to infer consumption by individual family members, just the family as a whole.

To measure patterns of nutritional well being at the individual level, we use data from the NHANES III, collected by the Center for Disease Control. The NHANES III was conducted between October 1988 and October 1994. It surveyed 33,994 people over 89 locations using a roving, mobile exam center. The NHANES is unique in that it combines demographic information, data from a standard clinical exam conducted by doctors (including blood tests) and questions about dietary intakes.

\section{Measures}


From the CEX, we derive measures for monthly expenditures in four different categories, food consumed in the home, food consumed outside of the home, clothing, and home fuel. Food in the home includes expenditures on all meals prepared at home, including picnics. Food outside the home includes expenditures at restaurants, cafes, fast food establishments, catered affairs, school and boarding house meals, and meals received as pay. Subsidized meals (such as free school breakfast) are not captured in the CEX measure of food expenditure, and we exclude expenditures on alcoholic beverages or tobacco from both measures of food. Home fuel includes expenditures on six fuels (heating oil, electricity, natural gas, coal, kerosene, and firewood) at primary residences. To account for inflation, we applied the Consumer Price Index deflator so that all expenditures are measured in constant 1982-1984 dollars.

We use three conceptually different measures of nutrition based on the NHANES data: calorie intake, dietary quality, and serum measures of vitamin and mineral deficiency. The first two measures are based on 24-hour dietary recall information in the NHANES, where individuals are asked to recount everything they ate in the last 24 hours. For most children under the age of 12 and for all children under age 6, their parents or guardians supplied dietary information.

Based on these responses, the NHANES provides an estimate of the total daily calorie intake and a measure of the dietary quality. The measure of dietary quality is based on the Health Eating Index (HEI), which was developed by scientists at the U.S. Department of Agriculture (USDA) to summarize how closely a diet meets USDA recommendations (Kennedy et al. 1995). Diets that feature fruits, vegetables, meat, and dairy in the right proportions receive higher scores in the HEI index, while diets that feature high levels of saturated and total fat and cholesterol receive lower scores. Intakes in ten different categories are scored on a scale from 0 to 10 (with 10 representing a good score), and then summed into a total score from 0 to 100. A two-point change in the HEI can reflect, for example, an extra daily serving of vegetables or a three-percentage point increase in the proportion of calories that come from fat.

Our vitamin deficiency measures are based upon low serum levels of the vitamin in question. We use age-specific normal values from standard pediatric and internal medicine textbooks to define inadequate serum levels of vitamins and minerals 
(DeAngelis et al. 1999 and Wilson et al. 1991). These normal values are shown in Appendix Table 5. We consider serum levels of vitamin A, C, and E. Because serum iron correlates poorly with inadequate body stores of iron, we instead use hematocrit and hemoglobin levels to diagnose anemia.

Table 1 presents basic descriptive statistics for both samples.

\section{Data Analysis}

Because the two datasets we analyze are structured differently, they require distinct, though closely related, empirical analysis. For the CEX, the unit of observation is the family, while for the NHANES, the unit of observation is the individual, though family relations are reported. For the CEX, we directly observe the state of residence and thus have matching temperature data available for each family in each month of observation. For the NHANES, the only geographic information that is publicly available for all samples members is the census region of the respondent (South, West, Midwest and Northeast) and whether the respondent lives in a large city, so we cannot link temperature information. However, we do know the interview month, so we can infer whether the respondent was surveyed in the summer or winter.

For the CEX analysis, our basic empirical strategy is to examine expenditure in four categories - food consumed inside the home, food consumed outside the home, clothing, and home fuel-in unseasonably cold or warm months. Because changes in expenditures over the course of a year by richer families are presumably not due to resource constraints, we use these families as a comparison group for the responses by poor families.

We construct a separate multivariate model of log expenditures for each of the four expenditure categories. Explanatory variables in these models include temperature, three income categories (the high income quartile, the middle two quartiles, and the low income quartile), the presence of children under age 18 in the family, income interacted with the presence of children, and temperature interacted with both income and the presence of children.

We include dummy variables for each year in each state to effectively de-trend expenditures separately for each state. We also include dummy variables for each month 
to allow for seasonal patterns in expenditures. After all these dummy variables are included, we are essentially left with variation in expenditures due to unseasonably cold and warm months. By including these dummy variables, we are no longer simply comparing outcomes in warm months with those in cold months. Instead, we are comparing, for instance, unusually cold Januarys with average Januarys. As a sensitivity check, we also estimated similar models with no dummy variables for state, month, or year and found similar results. Throughout, we use sample weights in model estimation.

With the estimated coefficients from the multivariate models, we predict expenditure changes resulting from an unseasonable $10^{\circ} \mathrm{F}$ drop in temperature for poor and rich families separately. These predictions are non-parametric retransformations of the regression coefficient using the Duan (1993) smearing technique.

In our analysis of the NHANES, we employ a similar empirical strategy, but instead of relying directly on outcome changes related to temperature changes, we rely on outcome changes across summer and winter. Specifically, we compare the compare the change in nutritional outcomes separately by age (children vs. adults) and income level (rich vs. poor). We consider an NHANES respondent to be a child if, at the time of the interview and examination, the respondent is under 18.

To make these nutritional comparisons, we construct linear multivariate models for each nutritional outcome, estimating separate models for children and adults. We use the same set of explanatory variables in each NHANES multivariate model. In addition to the key independent variables (whether a family is poor, whether the interview took place during the winter, and an interaction), these explanatory variables include a quadratic in age, a gender dummy, race dummies, and region-urban dummies. With the estimated coefficients from the multivariate models, we predict changes in nutritional outcomes between summer and winter for a reference rich person and a reference poor person. We rely the multivariate model to assess statistical significance. Again, we use sample weights in all model estimation.

There is an important caveat to our NHANES analysis. As is common in most large-scale surveys, the NHANES relies on a clustered probability sample to reduce survey costs. However, the clustering is much more concentrated in the NHANES than is typical in other surveys, presumably due to the high fixed costs of the mobile 
examination units. The consequence of this clustering is that the NHANES is intended to be nationally representative only when combining the first three years or the last three years of survey collection. Although we are combining all six years of data for our analyses, we are still sub-dividing the data by season and geography. Such an analysis strategy may not be supported by the sampling scheme, depending on the path that the mobile examination units travel. Overall, we believe these concerns are mitigated because our analysis strategy relies on combining results from the NHANES and the CEX to understand how consumption changes during cold weather.

For both the NHANES and CEX analyses, we estimate the models separately for different Census regions. The motivation for these regional sub-analyses is the intuitive notion that people in warmer areas of the country are likely to respond differently to temperature drops than are people in colder areas.

Since the main comparisons in our models are between summer and winter outcomes, it is natural to wonder whether our results are robust to less extreme comparisons, such as between spring and winter and between fall and winter. Since temperature changes between spring or fall and winter are smaller than changes between summer and winter, one would expect summer vs. winter to have the largest nutritional and budgetary effects, somewhere in between spring vs. winter or fall vs. winter effects. We conduct such sub-analyses using both the NHANES and the CEX. There are some limitations in the NHANES regional analysis imposed by the NHANES sampling scheme. In particular, models for winter vs. spring are not of full rank because the NHANES did not sample northeast rural areas in the spring, and models for winter vs. fall are not of full rank because the NHANES did not sample the urban midwest in the fall.

On a related point, if some families respond to low temperature shocks in the winter by cutting back on food, then it seems possible that some families respond to high temperature shocks in the summer with increased expenditures on air conditioning and decreased expenditures on food. This effect seems most likely to occur in the South, where high summer temperatures are often accompanied by humid conditions. We test for such "cool or eat" effects in Southern households using CEX data by limiting the sample to July and August and conducting analyses similar to the ones described above. 


\section{Results}

\section{CEX Results}

Table 2 shows our main results from the CEX. It consists of a series of regressions with our four different outcome variables, run with different sets of covariates. Both sets of regressions include ground temperature, income dummies, and interaction terms. However, the first set includes dummies for state and for year. Since temperature is measured for household's state in the month and year of observation, with these dummies, the variation left in temperature arises from month-to-month differences within states, and from year-to-year differences for a given month within states (caused perhaps by such weather events as El Nino). Since these sources of temperature variation (especially the former) are likely to be very typical for the state, we interpret these regressions as reflecting the effects of usual changes in temperature on family budgets.

The second set of regressions in Table 2 includes state dummies interacted with year dummies, along with a full set of month dummies. The main source of temperature variation in these regressions is year-to-year differences for a given month within states. Since these temperature changes are almost by definition unusual for the state, we interpret these regressions as reflecting the effects of unusual—and perhaps unexpected - changes in temperature on family budgets.

The key coefficient to read in Table 2 is the coefficient on ground temperature. A positive value indicates increased expenditures on these goods in response to increases in temperature for poor families. For rich families with incomes above the $75^{\text {th }}$ percentile, the effect of temperature changes are reflected in the sum of two coefficients - the ground temperature coefficient plus the ground temperature $* 75^{\text {th }}$ percentile income group dummy coefficient. Since these are log regressions, the coefficients reflect percentage changes in family budgets in response to absolute level changes in temperature.

Because regression coefficients such as these are often difficult to interpret, we construct graphs that reflect the changes in predicted expenditure implied by these regressions. Figure 1 reports the change in expenditures resulting from a $10^{\circ} \mathrm{F}$ drop in 
temperature for the four expenditure categories separately for rich and poor families. These predictions are based on the multivariate analysis of the CEX data. In this figure, increases in expenditures during periods of colder temperature are represented with positive bars, while decreases are represented with negative bars. All differences between expenditures by poor and rich families within categories are statically significant at the $\alpha=0.01$ level. As one might expect, expenditures on home fuel increased for both poor and richer families in unusually cold months. However, rich families increase home fuel expenditures by more than poor families - a $\$ 37 /$ month increase for poor families compared with a $\$ 53$ increase for rich families (in 1982-1984 dollars).

Expenditures on food in the home decreased in cold months for poor families but not for richer families. A $10^{\circ} \mathrm{F}$ drop in temperature is associated with a $\$ 9 /$ month decrease in such expenditures among poor families, compared with an $\$ 11 /$ month increase by richer families. This decrease in food expenditures by the poor are not offset by increased expenditures on food outside the home or on clothing. On the contrary, cold weather shocks are associated with only small changes in expenditures on clothing and food away from home in both types of families. The difference between rich and poor families in these categories is also small, though statistically significant.

Poor families spend a greater portion of their income on food than rich families do. They spend $29.5 \%$ of their budget on food in the home, compared with $22.5 \%$ by rich families. Food out of the home constitutes a much smaller portion of family budgets for both poor and rich families (5.3\% vs. 7.1\%). Hence, the net effect of cold weather months on food expenditures, both in and out of the home, is greatest on the poor.

For poor families, home fuel expenditures represent $12.3 \%$ of family budgets, while for rich families such expenditures represent $9.7 \%$ of budgets. In effect, the $\$ 37$ increase in home fuel expenditures during unusually cold months for poor families has a larger potential impact on family budgets than the $\$ 53$ increase for rich families, since it represents a larger share of the poor families' total budgets.

\section{NHANES Results}

Table 3 reports the predicted changes in nutritional outcomes between summer and winter based on the multivariate analysis of NHANES data. The regressions that 
underlie the numbers in Table 3 are shown in Appendix Tables 1a-1c. Because the unit of analysis in the NHANES is the individual rather than the family, we can estimate separate models for children, for adults, and for adults with children. As before, we compare outcomes in poor families with rich families.

Misnutrition is more prevalent among poor families than among rich families. Both adults with children and children in poor families exhibit lower levels of dietary quality, higher levels of serum vitamin deficiencies, and lower calorie intake (in winter only) than do their counterparts in rich families.

The winter resource shift induces a statistically significant reduction in caloric intake by both children and adults in poor families. Specifically, adults consume 147 fewer calories during then winter than in the summer (a 7.9\% decline), adults with children consume 241 fewer calories (an 11.6\% decline), and poor children consume 197 fewer calories (a 10.9\% decline). There are increases in the prevalence of vitamin deficiencies and anemia during the winter for children and for adults with children, but these increases are not statistically significant.

Children in rich families have worse diets in the winter than during the summer, but show no differences in serum measures. Rich adults (but not adults with children) are more likely to have low serum levels of vitamin A, C, or E in the winter, but show no changes in dietary quality. Rich adults and children eat higher quality diets and are less likely to have serum vitamin deficiencies than their poor counterparts. There are no other statistically significant differences in nutritional outcomes between summer and winter for rich families. Unlike poor families, there are no changes in caloric intake. The statistically significant differences that exist for members of rich families are unlikely to be explained by a "heat or eat" phenomenon, since these families increase expenditures on food in the winter.

If we use the summer-winter differences for richer families as a control group for poor families, then statistical tests demonstrate that only the winter caloric intake declines for members of poor families are significantly different from the rich $(\mathrm{p}<0.05$ for adults, $\mathrm{p}<0.05$ for adults with children, $\mathrm{p}<0.01$ for children). For no other summer-winter outcome differences do richer and poor families significantly differ, including dietary quality changes for children and vitamin deficiencies for adults. 


\section{Specification Tests}

\section{Heat or Eat in the South}

Because the South is, on average, warmer in the winter than other parts of the country, a winter temperature drop there can have different effects on family budgets than in other parts of the country. Consequently, we also analyze Southern households separately from other households. Table 4 shows the results from the CEX regressions when only Southern households are included in the analysis. Recall that the key coefficient to focus on is the one on ground temperature. Figures $2 \mathrm{a}$ and $2 \mathrm{~b}$ show the results from the CEX data for Southern regions. Figure 2a shows the results when only state and year fixed effects are included in the regression (which we interpret as the effects of typical temperature changes), while Figure $2 \mathrm{~b}$ shows the results when state by year and month fixed effects are included (which we interpret as the effect of unusual temperature changes).

As expected, compared to non-Southern households, fuel expenditures do not increase by as much in colder months (in models with non-interacted region, month, and year dummies), presumably because 10 degrees cooler in the South is more comfortable than is 10 degrees cooler in the North. On the other hand, we find larger increases in fuel expenditures in the South once we focus on unusual changes in temperature, though there is no change in food expenditures by poor families. Recall that unusual changes are defined as changes in temperature that differ significantly from the norm for the region in a given month. That unusual temperature drops can have larger effects on Southern fuel expenditures is not surprising given that homes there are less likely to have insulation. Information on insulation from the Department of Energy recommends (not surprisingly) that Northern homes be more fully insulated against cold. (http://www.eren.doe.gov/consumerinfo/energy_savers/insulation.html) To the extent that these recommendations are followed, this fact may explain why unusual cold periods in

the South — though perhaps infrequent - appear to have a large impact on fuel expenditures. 
As a test of whether Southern families are driving our main results about unusual temperature changes, we re-estimated all of our CEX models excluding households from the South. These results are reported in Figures $3 a$ (state and year fixed effects) and $3 b$ (state*year and month fixed effects), and in Table 5. The results tell the same story as when all households are included in the analysis, though the rise in fuel expenditures and the fall in food expenditures with dropping temperatures are not as pronounced. We conclude that "heat or eat" choices for the poor are not observable in the South, but are observable for households elsewhere.

\section{Summertime "Cool or Eat" in the South?}

One interpretation of our main results is that poor families are unable or unwilling buffer cold weather shocks to their fuel bills without decreasing food budgets and intake. Analogously, one might also think that hotter than normal months might affect food and energy expenditures in the same way, especially in humid southern regions during the summer months. Just as it is easy to find newspaper stories on the energy-related burdens faced by Northern families in the winter, one can find similar stories about Southern families in the summer, due to the use of air conditioning.

To see how important a "cool or eat" effect might be, we restricted our CEX sample to observations on households in Southern states in July and August. The results of our "cool or eat" investigations are reported in Table 6 and in Figures 4a and 4b. Unlike our main results, we find no evidence in favor of a "cool or eat" hypothesis. Neither rich nor poor households increase their fuel expenditure in Julys and Augusts that are 10 degrees warmer than usual. We checked in the CEX data to see if Southern households do, in fact, own air conditioners and an increasing majority do. For example, in $1998,97 \%$ of rich Southern households and $85 \%$ of poor Southern households report owning an air conditioner in the CEX - the comparable percentages for 1980 are $87 \%$ and $61 \%$. However, families do not increase expenditures on air conditioning in response to an unusual rise in temperatures. Taken in context, our results suggest that many poor Southern families "sweat" rather that spend extra money on cooling in unusually hot summers. 


\section{Lagged associations between temperature and fuel expenditure}

Our analyses using the CEX data relate colder than normal months to changes in food and energy expenditures. However, one might think that the relationship between temperature and fuel expenditure might be better modeled with a lag between experiencing an unusually cold month and incurring increased expenditures on energy. Energy bills might reflect energy use in the previous month or months. Also, it is possible that households accrue balances on their energy bills; thus, energy expenditures in a specific month likely reflect energy use in one or more previous months.

To explore this further, we estimated additional versions of the model including lagged effects. These versions of the food and fuel expenditure models include all the covariates in our usual model except that temperature is measured at time $t-l$ instead of at time $t$. These results are reported in Table 7 and in Figures 5a and 5b. In these specification tests, we find that unusual decreases in temperature are, in fact, more closely related to increases in fuel expenditure in the current month than in the following month, although they are associated with slight increases in expenditure in the following month suggesting that some expenditure on fuel is the result of accruing balances.

Finally, to test the relative effects of temperature changes at time $t$ and at time $t-1$ on family budgets, we ran another version of the food and fuel expenditure models that includes all the covariates in our usual model except that temperature is measured at time $t-1$ in addition to the temperature at time $t$. In this specification test, we find that higher fuel expenditures are, in fact, more strongly related to unusual decreases in temperature in the current month than in the previous month. We found that poor households respond to an unusual 10 degree decrease in temperature by increasing fuel expenditure in the current month by $\$ 11.4$, but increase fuel expenditure in the following month by only \$2.9. The fact that temperature in $t-1$ is correlated at all suggests that some fuel expenditures are the result of accruing balances, but that this effect is not as important as the concurrent effect of temperature changes on family budgets.

We are leery about our findings in these lag models for technical reasons. First, our measure of temperature is average monthly temperature so the cold spell could be several weeks distant from the time at which the expenditure is made, yet still be in the same month. Second, the CEX Interview survey requires consumers to retrospectively 
report how much they spend on each item for the past three months. For items that are purchased and received at the same point, it is clear when the expenditure took place, e.g. for food purchased in a grocery store. However, for items like heating bills it is unclear when the expenditure has taken place. To resolve this, the CEX asks a consumer to report the amount of his utility bill in the month in which is was received. The exact wording of the questions is as follows: "Since the first of [the month], have you received any bills for any of the following utilities, fuels or services." "Do you have any of these bills or other records showing these charges?" and "What was the amount of the bill?" Given these questions, it seems to us misreporting about when expenditures took place is more likely to be a problem than how much was spent.

\section{Comparing Winter to Fall and Winter to Spring in the NHANES}

In our main results, for the CEX we compared normal temperature months with unusually cold months, yet for the NHANES we compared outcomes in summer and winter. In order to test the sensitivity of our NHANES results to smaller changes in temperature, we also ran analyses comparing outcomes in the spring and fall separately against winter outcomes. Table 8 shows the results of the analysis comparing NHANES participants interviewed in the fall with those interviewed in the winter, while Table 9 compares winter and spring. The regression results underlying Table 8 are shown in Appendix Tables 3a-3c, while those underlying Table 9 are shown in Appendix Tables $2 \mathrm{a}-2 \mathrm{c}$. Because the sample varies in each of these regressions, and Tables 2, 7, and 8 report predicted values from these regressions, rather than sample means, it should not surprise readers that the values in these tables for winter participants vary among these tables. The key outcomes to examine are the differences between winter and the other seasons.

Relative to spring, poor adults consume worse diets (1.3 fewer HEI points for all adults, 2.8 fewer HEI points for adults with children), are more likely to have serum vitamin deficiencies, and consume fewer calories (160 fewer for all adults, 118 fewer for adults with children) in the winter. Again relative to the spring, rich adults are more likely to be vitamin deficient and anemic in the winter, and to consumer fewer calories. However, these results are not statistically significant for rich adults with children. 
Winter-spring differences are larger for poor adults than they are for richer adults. Poor children consume 145 fewer calories in the winter, while rich children have worse diets (2.4 fewer HEI points). Both of these differences for children are similar to the analogous summer-winter differences.

There are no statistically significant differences in nutritional outcomes for poor families in the winter relative to the fall. Rich adults, however, consume fewer calories in the winter (81 fewer for all adults, 237 fewer for adults with children). On average, rich children consume 94 more calories, are less likely to be anemic, but have worse diets in the winter than in the fall.

Broadly speaking these analyses reveal that for poor families, nutritional outcomes in winter are more like nutritional outcomes in the fall than they are like outcomes in the spring or summer. For poor families, both children and adults, the drop in caloric consumption lasts throughout the fall and winter, which is perhaps not surprising given that temperatures start to drop in the fall. Winter outcomes, generally, are worse than fall outcomes for these families, which is again not surprising given temperature drops and fluctuations are greater then. For richer families, winter nutritional outcomes seem generally worse than summer, spring, or fall outcomes. The drop in dietary quality for rich children in the winter seems to persist in all of our analyses.

\section{Comparing Across Regions in the NHANES}

Finally, because we found no evidence of wintertime decreases in food expenditures in poor Southern households, we re-estimate the NHANES nutritional outcomes comparing summer and winter while excluding Southern families. These results are shown in Table 10, while the regression results underlying this table are shown in Appendix Tables 4a-4c.

For poor families, the results in Table 10 are exactly like the results in Table 3 (where households from all regions are included), except the wintertime declines in caloric intake for adults and children are larger when Southern families are excluded. Poor children outside the South consume 292 fewer calories in the winter relative to the summer, poor adults without children consume 299 fewer calories, while poor adults with 
children consume 374 fewer calories. This is entirely consistent with our findings in the CEX that declines in food expenditures are greatest outside the South.

For children in rich families, the results in Table 10 are quite similar to those in Table 3. The only significant wintertime outcome change is in dietary quality. Rich children outside the South have worse diets (nearly 4 HEI points worse) in the winter than in the summer. For rich adults with children outside the South there is a large (12 percentage points) increase in the probability of vitamin deficiency. This increase is too large to be credible, and may reflect differences in the NHANES samples that we do not account for in this analysis. Finally, we find a 248-calorie winter decline in consumption by rich adults without children outside the south that is not present when southern households are included in the analysis. This likely reflects differences in tastes for dieting by single people between the South and the rest of the country.

\section{Alternative explanations for our findings}

There are at least two alternative explanations for our findings. First, enrollment by poor children in school meal programs during the school year could explain the decrease in food expenditures in low temperature months. This explanation, however, cannot account for the observed decreases in caloric intake during the winter for children. To check this explanation further, we conducted an additional analysis with the CEX data restricting the sample to families with children who were below school-age. Table 11 and Figures $7 \mathrm{a}$ and $7 \mathrm{~b}$ show the results for this analysis. For this sub-sample, we find similar declines in food expenditure and increases in home fuel during cold months. (Poor families increase their fuel expenditure by $\$ 10.4$ and reduce their food expenditure by $\$ 6.6$ in response to an unusually cold month. While rich families increase their fuel expenditure by $\$ 15.6$, they do not reduce their food expenditure). Since children below school-age are presumably not enrolled in school lunch programs, these programs cannot explain the observed expenditure patterns.

A second alternative explanation for our results is that nutritious food, such as fresh fruits and vegetables, is cheaper and readily available in the summer. Such an explanation might rationalize declining dietary quality in winter months, especially for poor families who cannot afford the expense of high quality winter diets. However, this 
explanation is inconsistent with a decline in food expenditure in cold months. A textbook result in economics is that expenditures on a good increase with price so long as that good is relatively unresponsive to price. It is a consistent empirical result that the demand for food is relatively unresponsive to price. For a recent estimate confirming this fact in the United States, see van Driel, et al. (1997). Given this fact, if the price of high quality food rises in the winter, then expenditures should also increase. Therefore, our demonstration that expenditures decrease in the winter is inconsistent with this alternative explanation.

\section{Discussion}

We investigate how well poor American families protect against nutritional risk due to budget shocks from cold weather. We find that poor families reduce their expenditure on food in response to unusually cold weather, while richer families do not. Among poor families, we estimate that a monthly temperature that was $10^{\circ} \mathrm{F}$ colder than normal would result in a reduction in expenditures on food in the home by $\$ 11 /$ month and an increase in fuel expenditures by $\$ 37 /$ month. Adults and children alike in poor households reduce their caloric intake by 10 percent during the winter months, whereas rich family members do not reduce their caloric intake during the winter.

Our results based on the CEX can be summarized as follows. Poor families decrease their expenditures on food in unusually low temperature months. Both poor families and richer families increase heating expenditures - but the increase for the poor is less than that for rich families, though the change is a larger proportion of poor families' budgets.

Using the NHANES we find that in poor families, both adults and children reduce their caloric intake during the winter. In rich families, nutritional outcomes do not generally significantly differ between summer and winter for either adults or children, with the exception that dietary quality declines for children and serum vitamin deficiencies increase for adults (but not adults with children). Too much should not be made of the finding for rich families because even the winter diets of rich children are of a higher quality than the summer diets of poor children, and rich adults are always less likely than their poor counterparts to have serum vitamin deficiencies. When rich 
families are used as a control group for poor families, only the winter declines in the caloric intake for poor families are statistically significant. It is striking that the impact of cold weather shocks on nutritional outcomes corresponds so closely with the impact on expenditures.

Our results suggest that poor American families with children face stark choices in cold weather. In particular, they increase home fuel expenditures at the cost of expenditures on food and nutritional well being. Our evidence also suggests that poor parents are only imperfectly able to protect their children from the effects of cold weather shocks. Both children and adults reduce their caloric intake during winter months.

Given the importance of food to well being, it seems implausible that poor families would reduce food expenditures in the winter lightly. If these families had access to short-term credit market or to savings, they would borrow or dip into savings to pay for high winter fuel needs, rather than reduce food expenditures. Given our results, it is likely that these families do not have access to such resources. Our results are consistent with the finding that nearly $25 \%$ of American families with income below \$25,600 have neither savings nor checking accounts (Hogarth and O'Donnell 1999).

Our results should be considered in the context of another public health problem - increasing rates of obesity, especially among the poor (see Popkin and Doak, 1998 or Flegal, 1996 for reviews of national and international trends in obesity; also see James et. al., 1998 and Olson, 1999 for a discussion of the relationship between poverty, nutrition, and obesity in developed countries). It is unclear whether declines in calorie intake should be seen as an unmitigated disaster, since this decline is not accompanied by changes in dietary quality, serum vitamin deficiency, or anemia rates. However, increased variance in calorie intake, which is what our results imply, may not have the same positive or even desirable health consequences as more constant caloric restrictions for the obese.

Finally, there are many social programs that are meant to help poor families weather detrimental economic events, including Food Stamps, school meal programs, and long term repayment plans offered by utility companies. Our results suggest that existing social programs, taken together, are insufficient to buffer poor families from cold weather shocks to family budgets. 


\section{References}

Bhattacharya J. and J. Currie (2001) "Youths at Nutritional Risk: Misnourished or Malnourished?" in Risky Behavior among Youths, Jonathon Gruber (ed.), University of Chicago Press.

DeAngelis CD, Feigin RD, Warshaw JB, and McMillan JA. (1999) Oski's Pediatrics : principles and practice 3rd ed. Philadelphia : Lippincott Williams \& Wilkins.

Devaney BL; Gordon AR; Burghardt JA. (1995) "Dietary intakes of students," American Journal of Clinical Nutrition, 61(1 suppl):205S-212S.

Duan N. Smearing estimate: A nonparametric retransformation method. Journal of the American Statistical Association. 1983 Sept; 78:605-610.

Flegal KM (1996) "Trends in body weight and overweight in the U.S. population" Nutrition Reviews, 54(4 Pt 2):S97-100

Frank DA; Roos N; Meyers A; Napoleone M et al. (1996) "Seasonal variation in weightfor-age in a pediatric emergency room." Public Health Reports, 111(4):366-71.

Hogarth JM and O'Donnell KH (1999) "Banking Relationships of Lower-Income Families and the Governmental Trend Toward Electronic Payment," Federal Reserve Bulletin, July 1999: 459-470.

James WP, Nelson M, Ralph A, Leather S.(1997) "Socioeconomic determinants of health. The contribution of nutrition to inequalities in health." BMJ, 314(7093):1545-9

Kennedy, Eileen, James Ohls, Steven Carlson, and Kathryn Fleming. (1995) "The Healthy Eating Index: Design and Applications", Journal of the American Dietetic Association, October, 95 \#10: 1103-1108.

Lawlor DA; Harvey D; Dews HG. (2000) Investigation of the association between excess winter mortality and socio-economic deprivation. Journal of Public Health Medicine, Jun, 22(2):176-81.

Middleman AB, Emans SJ, and Cox J. (1996) "Nutritional Vit B12 Deficiency and Folate Deficiency in an Adolescent Patient Presenting with Anemia, Weight Loss, and Poor School Performance." Journal of Adolescent Health 19:76-9

Olson CM (1999) "Nutrition and health outcomes associated with food insecurity and hunger." Journal of Nutrition, 129(2S Suppl):521S-524S

Popkin BM, Doak CM (1998) "The obesity epidemic is a worldwide phenomenon" Nutrition Reviews, 56(4 Pt 1):106-14 
Shah S; Peacock J. (1999) Deprivation and excess winter mortality. Journal of Epidemiology and Community Health, Aug, 53(8):499-502.

U.S. Centers for Disease Control, (1996) "Guidelines for School Programs to Promote Lifelong Healthy Eating," Morbidity and Mortality Weekly Report 45(RR-9).

van Driel H; Nadall, V; Zeelenberg, K (1997) "The Demand for Food in the United States and the Netherlands: A Systems Approach with the CBS Model" v12, n5 (Sept.Oct. 1997): 509-23 Journal of Applied Econometrics

Wilde P. (1997) “A Monthly Cycle in Food Use by Food Stamp Recipients." Paper presented at research briefing, Board on Children, Youth and Familes, May 19-20, 1997. Cornell University. Cited in Bridgeman A, Phillips D. (eds.) (1998) New Findings on Child Health, Poverty, and Nutrition: Summary of a Research Briefing. Washington D.C.: National Academy Press.

Wilde P, Ranney C. (1997) "A Monthly Cycle in Food Expenditure and Intake by Participants in the U.S. Food Stamp Program. Working Paper 97-04. Department of Agricultural, Resource, and Managerial Economics, Cornell University.

Wilson JD; Braunwald E; Isselbacher KJ; Petersdorf RG; Martin JB; Fauci AS; Root RK (eds.) (1991) Harrison's Principles of Internal Medicine (New York: McGraw-Hill). 
Table 1: Descriptive Characteristics for the CEX and NHANES

\begin{tabular}{lcc}
\hline \hline CEX Variables & Mean & Std. Dev. \\
\hline Monthly expenditures: food in & 200.6 & 141.2 \\
Monthly expenditures: food out & 77.6 & 173.5 \\
Monthly expenditures: clothing & 69.4 & 160.4 \\
Monthly expenditures: fuel & 74.0 & 70.5 \\
Annual income & 19,276 & 19,230 \\
Income group: poor & 0.223 & 0.416 \\
Income group: middle & 0.449 & 0.497 \\
Income group: rich & 0.328 & 0.470 \\
\hline NHANES Variables—Children & Mean & Std. Dev. \\
\hline Dietary quality (HEI) & 65.0 & 12.4 \\
Anemia & 0.064 & 0.245 \\
Short A, C, or E & 0.121 & 0.326 \\
Daily calories & 1933 & 965 \\
Income group: poor & 0.581 & 0.493 \\
Income group: rich & 0.419 & 0.493 \\
Season: winter & 0.155 & 0.362 \\
Season: spring & 0.295 & 0.456 \\
Season: summer & 0.259 & 0.438 \\
Season: fall & 0.291 & 0.454 \\
\hline NHANES Variables-Adults & Mean & Std. Dev. \\
\hline Dietary quality (HEI) & 64.0 & 13.1 \\
Anemia & 0.060 & 0.238 \\
Short A, C, or E & 0.125 & 0.331 \\
Daily calories & 2204 & 1077 \\
Income group: poor & 0.342 & 0.474 \\
Income group: rich & 0.658 & 0.474 \\
Season: winter & 0.138 & 0.344 \\
Season: spring & 0.282 & 0.450 \\
Season: summer & 0.297 & 0.457 \\
Season: fall & 0.283 & 0.451 \\
Children in household & 0.364 & 0.481 \\
\hline \hline & & \\
\hline
\end{tabular}

Notes: The CEX tabulations rely on 1980 to 1998 interviews. Expenditure categories are for real monthly expenditure and income is real annual income (1982-1984 dollars). Poor indicates 25th percentile of real income or less and rich indicates 75th percentile of real income or more. The NHANES tabulations are based on all individuals who have income less than 1.5 of the poverty line (the poor) or income greater than 3.0 of the poverty line (the rich); the rest of the individuals are dropped. There are some missing data, which reduces the sample size for some analysis. For example, we do not have blood measures for individuals under the age of 3. Children are defined as individuals 17 or under, and adults are defined as those above 17. Dietary quality is measured with the Healthy Eating Index (HEI). 
Table 2: CEX Regressions for All Four Regions

\begin{tabular}{|c|c|c|c|c|}
\hline & $\begin{array}{l}\text { Food In the } \\
\text { Home }\end{array}$ & $\begin{array}{c}\text { Food Out of } \\
\text { Home }\end{array}$ & Clothing & Home Fuel \\
\hline \multirow[t]{2}{*}{ Ground Temperature } & $1.54 \mathrm{E}-03$ & $1.62 \mathrm{E}-03$ & $-4.07 \mathrm{E}-04$ & $-6.82 \mathrm{E}-03$ \\
\hline & [9.51e-05] & {$[1.71 \mathrm{e}-04]$} & {$[2.63 \mathrm{e}-04]$} & {$[1.15 \mathrm{e}-04]$} \\
\hline \multirow{2}{*}{$\begin{array}{l}\text { Ground Temperature } \\
\text { *Inc } 2574\end{array}$} & $-1.46 \mathrm{E}-03$ & $2.93 \mathrm{E}-04$ & $-7.24 \mathrm{E}-04$ & $-4.13 \mathrm{E}-04$ \\
\hline & {$[1.13 \mathrm{e}-04]$} & [1.98e-04] & [3.02e-04] & [1.34e-04] \\
\hline \multirow{2}{*}{$\begin{array}{l}\text { Ground Temperature } \\
\text { *Inc75 }\end{array}$} & $-1.75 \mathrm{E}-03$ & 8.92E-04 & $-6.40 \mathrm{E}-04$ & $1.06 \mathrm{E}-04$ \\
\hline & {$[1.20 \mathrm{e}-04]$} & {$[2.05 \mathrm{e}-04]$} & [3.12e-04] & [1.40e-04] \\
\hline \multirow{2}{*}{$\begin{array}{l}\text { Income in } 25 \text { th to } \\
\text { 74th Percentile Range }\end{array}$} & $4.25 \mathrm{E}-01$ & 4.23E-01 & $3.37 \mathrm{E}-01$ & $2.14 \mathrm{E}-01$ \\
\hline & {$[6.50 \mathrm{e}-03]$} & {$[1.13 \mathrm{e}-02]$} & {$[1.72 \mathrm{e}-02]$} & [7.72e-03] \\
\hline \multirow{2}{*}{$\begin{array}{l}\text { Income in } 75 \text { th or } \\
\text { above Percentile Range }\end{array}$} & $7.41 \mathrm{E}-01$ & $9.22 \mathrm{E}-01$ & 8.07E-01 & $4.88 \mathrm{E}-01$ \\
\hline & [6.86e-03] & {$[1.17 \mathrm{e}-02]$} & {$[1.78 \mathrm{e}-02]$} & [8.07e-03] \\
\hline \multirow[t]{2}{*}{ Constant } & $4.81 \mathrm{E}+00$ & $3.40 \mathrm{E}+00$ & $3.79 \mathrm{E}+00$ & $4.29 \mathrm{E}+00$ \\
\hline & {$[6.30 \mathrm{e}-03]$} & [1.11e-02] & {$[1.68 \mathrm{e}-02]$} & {$[7.59 \mathrm{e}-03]$} \\
\hline State and Year & Yes & Yes & Yes & Yes \\
\hline State*Year and Month & No & No & No & No \\
\hline R-squared & 0.1178 & 0.1136 & 0.0556 & 0.0764 \\
\hline \multirow[t]{2}{*}{$\mathrm{N}$} & 853307 & 711646 & 469543 & 747005 \\
\hline & $\begin{array}{l}\text { Food In the } \\
\text { Home }\end{array}$ & $\begin{array}{l}\text { Food Out of } \\
\text { Home }\end{array}$ & Clothing & Home Fuel \\
\hline \multirow[t]{2}{*}{ Ground Temperature } & $1.02 \mathrm{E}-03$ & $2.31 \mathrm{E}-05$ & $3.21 \mathrm{E}-04$ & $-9.31 \mathrm{E}-03$ \\
\hline & [2.01e-04] & [3.34e-04] & [4.98e-04] & [2.31e-04] \\
\hline \multirow{2}{*}{$\begin{array}{l}\text { Ground Temperature } \\
\text { *Inc2574 }\end{array}$} & $-1.42 \mathrm{E}-03$ & $3.00 \mathrm{E}-04$ & $-8.93 \mathrm{E}-04$ & $-3.29 \mathrm{E}-04$ \\
\hline & [1.13e-04] & {$[1.97 \mathrm{e}-04]$} & [2.96e-04] & [1.33e-04] \\
\hline \multirow{2}{*}{$\begin{array}{l}\text { Ground Temperature } \\
\text { *Inc75 }\end{array}$} & $-1.69 \mathrm{E}-03$ & $9.16 \mathrm{E}-04$ & $-8.76 \mathrm{E}-04$ & $1.16 \mathrm{E}-04$ \\
\hline & {$[1.20 \mathrm{e}-04]$} & {$[2.05 \mathrm{e}-04]$} & [3.07e-04] & [1.40e-04] \\
\hline \multirow{2}{*}{$\begin{array}{l}\text { Income in } 25 \text { th to } \\
\text { 74th Percentile Range }\end{array}$} & $4.21 \mathrm{E}-01$ & $4.24 \mathrm{E}-01$ & $3.53 \mathrm{E}-01$ & $2.09 \mathrm{E}-01$ \\
\hline & [6.48e-03] & {$[1.13 \mathrm{e}-02]$} & {$[1.69 \mathrm{e}-02]$} & [7.67e-03] \\
\hline \multirow{2}{*}{$\begin{array}{l}\text { Income in } 75 \text { th or } \\
\text { above Percentile Range }\end{array}$} & $7.36 \mathrm{E}-01$ & $9.21 \mathrm{E}-01$ & $8.27 \mathrm{E}-01$ & $4.88 \mathrm{E}-01$ \\
\hline & [6.84e-03] & {$[1.17 \mathrm{e}-02]$} & {$[1.75 \mathrm{e}-02]$} & [8.02e-03] \\
\hline \multirow[t]{2}{*}{ Constant } & $4.66 \mathrm{E}+00$ & $3.37 \mathrm{E}+00$ & $3.42 \mathrm{E}+00$ & $4.44 \mathrm{E}+00$ \\
\hline & [1.47e-02] & [1.38e-02] & [2.08e-02] & [9.52e-03] \\
\hline State and Year & No & No & No & No \\
\hline State*Year and Month & Yes & Yes & Yes & Yes \\
\hline R-squared & 0.1072 & 0.1084 & 0.0859 & 0.0724 \\
\hline $\mathrm{N}$ & 853307 & 711646 & 469543 & 747005 \\
\hline
\end{tabular}


Table 3: Nutritional Outcomes in Winter and Summer

\begin{tabular}{|c|c|c|c|c|c|c|c|}
\hline & & \multicolumn{3}{|c|}{ Poor Families $^{\mathrm{a}}$} & \multicolumn{3}{|c|}{ Richer Families $^{b}$} \\
\hline Group & Nutritional Outcomes & Summer & Winter & Difference & Summer & Winter & Difference \\
\hline \multirow{5}{*}{$\begin{array}{c}\text { All } \\
\text { Adults } \\
\mathrm{N}=4,808\end{array}$} & Dietary Quality $^{\mathrm{c}}$ & 59.8 & 60.1 & 0.3 & 64.3 & 64.9 & 0.6 \\
\hline & Serum Measures & & & & & & \\
\hline & Anemia & 0.081 & 0.097 & 0.016 & 0.076 & 0.091 & 0.015 \\
\hline & Low $A, C$, or $E$ & 0.242 & 0.268 & 0.026 & 0.087 & 0.130 & $0.043^{*}$ \\
\hline & Calories & 1858 & 1711 & $-147^{*}$ & 1847 & 1841 & -6 \\
\hline \multirow{5}{*}{$\begin{array}{c}\text { Adults } \\
\text { with } \\
\text { children, } \\
\mathrm{N}=1,994\end{array}$} & Dietary Quality $^{\mathrm{c}}$ & 55.3 & 55.4 & 0.1 & 59.9 & 60.8 & 0.9 \\
\hline & Serum Measures & & & & & & \\
\hline & Anemia & 0.072 & 0.085 & 0.013 & 0.056 & 0.077 & 0.021 \\
\hline & Low $A, C$, or $E$ & 0.191 & 0.251 & 0.061 & 0.027 & 0.093 & 0.067 \\
\hline & Calories & 2072 & 1831 & $-241^{*}$ & 1998 & 1973 & -26 \\
\hline \multirow{5}{*}{$\begin{array}{l}\text { Children, } \\
\mathrm{N}=3,779\end{array}$} & Dietary Quality $^{\mathrm{c}}$ & 64.2 & 63.3 & -1.0 & 67.2 & 64.9 & $-2.3^{*}$ \\
\hline & Serum Measures & & & & & & \\
\hline & Anemia & 0.000 & 0.021 & 0.021 & 0.001 & 0.025 & 0.024 \\
\hline & Low A, C, or E & 0.097 & 0.133 & 0.037 & 0.051 & 0.058 & 0.007 \\
\hline & Calories & 1807 & 1611 & $-197^{\text {** }}$ & 1719 & 1713 & -7 \\
\hline
\end{tabular}

Source: Authors' tabulations from the NHANES.

Notes: These outcomes are based on a regression analysis in which we estimate separate models for each outcome and age (children and adults). In addition to the key independent variables of income levels and season of interview, the regressions include race dummies, a quadratic in age, eight region dummies, and a gender dummy. The results from these regressions are shown in Appendix Tables 1a-1c. The outcomes are the predicted outcome for a standardized person (a white female from the urban Northeast); the age of the child is 8 and the age of the adult is 35 . The statistical tests are based on the coefficients of the regression, according to the following levels: * for 0.05 and $* *$ for 0.01 . The only statistically significant difference between adults and children is for rich families in dietary quality $(\alpha<0.05)$.

${ }^{a}$ Poor families have a poverty-income ratio less than 1.5 .

${ }^{\mathrm{b}}$ Richer families have a poverty-income ratio greater than 3 .

${ }^{\mathrm{c}}$ Dietary quality is measured using the Health Eating Index (on a scale from 0 to 100 ) — see text for an explanation. 
Table 4: Results for Southern Regions

\begin{tabular}{|c|c|c|c|c|}
\hline & $\begin{array}{l}\text { Food In the } \\
\text { Home }\end{array}$ & $\begin{array}{l}\text { Food Out of } \\
\text { Home }\end{array}$ & Clothing & Home Fuel \\
\hline Ground Temperature & $\begin{array}{c}1.45 \mathrm{E}-03 \\
{[2.12 \mathrm{e}-04]}\end{array}$ & $\begin{array}{c}2.32 \mathrm{E}-03 \\
{[3.94 \mathrm{e}-04]}\end{array}$ & $\begin{array}{c}1.11 \mathrm{E}-03 \\
{[6.05 \mathrm{e}-04]}\end{array}$ & $\begin{array}{l}-2.95 \mathrm{E}-03 \\
{[2.30 \mathrm{e}-04]}\end{array}$ \\
\hline $\begin{array}{l}\text { Ground Temperature } \\
\text { *Inc } 2574\end{array}$ & $\begin{array}{l}-1.12 \mathrm{E}-03 \\
{[2.53 \mathrm{e}-04]}\end{array}$ & $\begin{array}{l}-7.39 \mathrm{E}-05 \\
{[4.53 \mathrm{e}-04]}\end{array}$ & $\begin{array}{l}-1.86 \mathrm{E}-03 \\
{[6.94 \mathrm{e}-04]}\end{array}$ & $\begin{array}{c}1.63 \mathrm{E}-03 \\
{[2.70 \mathrm{e}-04]}\end{array}$ \\
\hline $\begin{array}{l}\text { Ground Temperature } \\
* \text { Inc75 }\end{array}$ & $\begin{array}{l}-2.32 \mathrm{E}-03 \\
{[2.71 \mathrm{e}-04]}\end{array}$ & $\begin{array}{l}-3.16 \mathrm{E}-04 \\
{[4.74 \mathrm{e}-04]}\end{array}$ & $\begin{array}{l}-1.42 \mathrm{E}-03 \\
{[7.22 \mathrm{e}-04]}\end{array}$ & $\begin{array}{c}2.10 \mathrm{E}-03 \\
{[2.85 \mathrm{e}-04]}\end{array}$ \\
\hline $\begin{array}{l}\text { Income in 25th to } \\
\text { 74th Percentile Range }\end{array}$ & $\begin{array}{c}3.76 \mathrm{E}-01 \\
{[1.65 \mathrm{e}-02]}\end{array}$ & $\begin{array}{l}4.50 \mathrm{E}-01 \\
{[2.96 \mathrm{e}-02]}\end{array}$ & $\begin{array}{c}4.34 \mathrm{E}-01 \\
{[4.52 \mathrm{e}-02]}\end{array}$ & $\begin{array}{c}7.05 \mathrm{E}-02 \\
{[1.77 \mathrm{e}-02]}\end{array}$ \\
\hline $\begin{array}{l}\text { Income in } 75 \text { th or } \\
\text { above Percentile Range }\end{array}$ & $\begin{array}{c}7.65 \mathrm{E}-01 \\
{[1.77 \mathrm{e}-02]}\end{array}$ & $\begin{array}{c}1.02 \mathrm{E}+00 \\
{[3.09 \mathrm{e}-02]}\end{array}$ & $\begin{array}{c}9.00 \mathrm{E}-01 \\
{[4.69 \mathrm{e}-02]}\end{array}$ & $\begin{array}{c}3.65 \mathrm{E}-01 \\
{[1.87 \mathrm{e}-02]}\end{array}$ \\
\hline Constant & $\begin{array}{l}4.82 \mathrm{E}+00 \\
{[1.52 \mathrm{e}-02]}\end{array}$ & $\begin{array}{l}3.36 \mathrm{E}+00 \\
{[2.78 \mathrm{e}-02]}\end{array}$ & $\begin{array}{l}3.69 \mathrm{E}+00 \\
{[4.24 \mathrm{e}-02]}\end{array}$ & $\begin{array}{l}4.16 \mathrm{E}+00 \\
{[1.65 \mathrm{e}-02]}\end{array}$ \\
\hline State and Year & Yes & Yes & Yes & Yes \\
\hline State*Year and Month & No & No & No & No \\
\hline R-squared & 0.114 & 0.1156 & 0.0582 & 0.0848 \\
\hline $\mathrm{N}$ & 246563 & 203335 & 134401 & 218912 \\
\hline & $\begin{array}{c}\text { Food In the } \\
\text { Home }\end{array}$ & $\begin{array}{c}\text { Food Out of } \\
\text { Home }\end{array}$ & Clothing & Home Fuel \\
\hline Ground Temperature & $\begin{array}{c}3.53 \mathrm{E}-05 \\
{[4.63 \mathrm{e}-04]}\end{array}$ & $\begin{array}{l}2.98 \mathrm{E}-04 \\
{[7.84 \mathrm{e}-04]}\end{array}$ & $\begin{array}{c}8.98 \mathrm{E}-05 \\
{[1.19 \mathrm{e}-03]}\end{array}$ & $\begin{array}{l}-1.32 \mathrm{E}-02 \\
{[4.77 \mathrm{e}-04]}\end{array}$ \\
\hline $\begin{array}{l}\text { Ground Temperature } \\
\text { *Inc } 2574\end{array}$ & $\begin{array}{l}-1.02 \mathrm{E}-03 \\
{[2.52 \mathrm{e}-04]}\end{array}$ & $\begin{array}{l}-1.07 \mathrm{E}-04 \\
{[4.53 \mathrm{e}-04]}\end{array}$ & $\begin{array}{l}-2.11 \mathrm{E}-03 \\
{[6.84 \mathrm{e}-04]}\end{array}$ & $\begin{array}{c}1.73 \mathrm{E}-03 \\
{[2.66 \mathrm{e}-04]}\end{array}$ \\
\hline $\begin{array}{l}\text { Ground Temperature } \\
* \text { Inc } 75\end{array}$ & $\begin{array}{l}-2.17 \mathrm{E}-03 \\
{[2.70 \mathrm{e}-04]}\end{array}$ & $\begin{array}{l}-3.71 \mathrm{E}-04 \\
{[4.74 \mathrm{e}-04]}\end{array}$ & $\begin{array}{l}-1.81 \mathrm{E}-03 \\
{[7.11 \mathrm{e}-04]}\end{array}$ & $\begin{array}{c}2.30 \mathrm{E}-03 \\
{[2.82 \mathrm{e}-04]}\end{array}$ \\
\hline $\begin{array}{l}\text { Income in 25th to } \\
\text { 74th Percentile Range }\end{array}$ & $\begin{array}{c}3.68 \mathrm{E}-01 \\
{[1.65 \mathrm{e}-02]}\end{array}$ & $\begin{array}{c}4.54 \mathrm{E}-01 \\
{[2.96 \mathrm{e}-02]}\end{array}$ & $\begin{array}{c}4.57 \mathrm{E}-01 \\
{[4.46 \mathrm{e}-02]}\end{array}$ & $\begin{array}{c}6.58 \mathrm{E}-02 \\
{[1.75 \mathrm{e}-02]}\end{array}$ \\
\hline $\begin{array}{l}\text { Income in } 75 \text { th or } \\
\text { above Percentile Range }\end{array}$ & $\begin{array}{c}7.53 \mathrm{E}-01 \\
{[1.76 \mathrm{e}-02]}\end{array}$ & $\begin{array}{c}1.02 \mathrm{E}+00 \\
{[3.09 \mathrm{e}-02]}\end{array}$ & $\begin{array}{c}9.34 \mathrm{E}-01 \\
{[4.63 \mathrm{e}-02]}\end{array}$ & $\begin{array}{c}3.51 \mathrm{E}-01 \\
{[1.84 \mathrm{e}-02]}\end{array}$ \\
\hline Constant & $\begin{array}{l}4.67 \mathrm{E}+00 \\
{[2.31 \mathrm{e}-02]}\end{array}$ & $\begin{array}{c}3.43 \mathrm{E}+00 \\
{[6.13 \mathrm{e}-02]}\end{array}$ & $\begin{array}{c}3.34 \mathrm{E}+00 \\
{[5.99 \mathrm{e}-02]}\end{array}$ & $\begin{array}{l}5.09 \mathrm{E}+00 \\
{[3.76 \mathrm{e}-02]}\end{array}$ \\
\hline State and Year & No & No & No & No \\
\hline State*Year and Month & Yes & Yes & Yes & Yes \\
\hline R-squared & 0.1002 & 0.1094 & 0.0855 & 0.0972 \\
\hline $\mathrm{N}$ & 246563 & 203335 & 134401 & 218912 \\
\hline
\end{tabular}


Table 5: Results for Non-Southern Regions

\begin{tabular}{|c|c|c|c|c|}
\hline & $\begin{array}{l}\text { Food In the } \\
\text { Home }\end{array}$ & $\begin{array}{l}\text { Food Out of } \\
\text { Home }\end{array}$ & Clothing & Home Fuel \\
\hline Ground Temperature & $\begin{array}{l}1.24 \mathrm{E}-03 \\
{[1.13 \mathrm{e}-04]}\end{array}$ & $\begin{array}{l}1.57 \mathrm{E}-03 \\
{[2.02 \mathrm{e}-04]}\end{array}$ & $\begin{array}{l}-3.09 \mathrm{E}-04 \\
{[3.10 \mathrm{e}-04]}\end{array}$ & $\begin{array}{l}-7.91 \mathrm{E}-03 \\
{[1.43 \mathrm{e}-04]}\end{array}$ \\
\hline $\begin{array}{l}\text { Ground Temperature } \\
{ }^{*} \text { Inc } 2574\end{array}$ & $\begin{array}{l}-1.04 \mathrm{E}-03 \\
{[1.37 \mathrm{e}-04]}\end{array}$ & $\begin{array}{c}3.17 \mathrm{E}-04 \\
{[2.37 \mathrm{e}-04]}\end{array}$ & $\begin{array}{l}-8.80 \mathrm{E}-04 \\
{[3.60 \mathrm{e}-04]}\end{array}$ & $\begin{array}{l}-7.76 \mathrm{E}-04 \\
{[1.68 \mathrm{e}-04]}\end{array}$ \\
\hline $\begin{array}{l}\text { Ground Temperature } \\
\text { *Inc75 }\end{array}$ & $\begin{array}{l}-1.29 \mathrm{E}-03 \\
{[1.44 \mathrm{e}-04]}\end{array}$ & $\begin{array}{c}8.81 \mathrm{E}-04 \\
{[2.45 \mathrm{e}-04]}\end{array}$ & $\begin{array}{l}-1.20 \mathrm{E}-03 \\
{[3.71 \mathrm{e}-04]}\end{array}$ & $\begin{array}{l}-4.94 \mathrm{E}-04 \\
{[1.76 \mathrm{e}-04]}\end{array}$ \\
\hline $\begin{array}{l}\text { Income in } 25 \text { th to } \\
\text { 74th Percentile Range }\end{array}$ & $\begin{array}{l}4.15 \mathrm{E}-01 \\
{[7.37 \mathrm{e}-03]}\end{array}$ & $\begin{array}{c}4.20 \mathrm{E}-01 \\
{[1.27 \mathrm{e}-02]}\end{array}$ & $\begin{array}{c}3.35 \mathrm{E}-01 \\
{[1.93 \mathrm{e}-02]}\end{array}$ & $\begin{array}{c}2.36 \mathrm{E}-01 \\
{[9.07 \mathrm{e}-03]}\end{array}$ \\
\hline $\begin{array}{l}\text { Income in } 75 \text { th or } \\
\text { above Percentile Range }\end{array}$ & $\begin{array}{l}7.24 \mathrm{E}-01 \\
{[7.76 \mathrm{e}-03]}\end{array}$ & $\begin{array}{c}9.15 \mathrm{E}-01 \\
{[1.32 \mathrm{e}-02]}\end{array}$ & $\begin{array}{c}8.18 \mathrm{E}-01 \\
{[1.99 \mathrm{e}-02]}\end{array}$ & $\begin{array}{c}5.16 \mathrm{E}-01 \\
{[9.45 \mathrm{e}-03]}\end{array}$ \\
\hline Constant & $\begin{array}{l}4.81 \mathrm{E}+00 \\
{[7.10 \mathrm{e}-03]}\end{array}$ & $\begin{array}{c}3.41 \mathrm{E}+00 \\
{[1.24 \mathrm{e}-02]}\end{array}$ & $\begin{array}{c}3.79 \mathrm{E}+00 \\
{[1.87 \mathrm{e}-02]}\end{array}$ & $\begin{array}{c}4.30 \mathrm{E}+00 \\
{[8.86 \mathrm{e}-03]}\end{array}$ \\
\hline State and Year & Yes & Yes & Yes & Yes \\
\hline State*Year and Month & No & No & No & No \\
\hline R-squared & 0.1197 & 0.1132 & 0.0547 & 0.0912 \\
\hline $\mathrm{N}$ & 606744 & 508311 & 335142 & 528093 \\
\hline & $\begin{array}{c}\text { Food In the } \\
\text { Home }\end{array}$ & $\begin{array}{c}\text { Food Out of } \\
\text { Home }\end{array}$ & Clothing & Home Fuel \\
\hline Ground Temperature & $\begin{array}{c}7.68 \mathrm{E}-04 \\
{[2.40 \mathrm{e}-04]}\end{array}$ & $\begin{array}{l}-2.11 \mathrm{E}-05 \\
{[3.97 \mathrm{e}-04]}\end{array}$ & $\begin{array}{c}1.66 \mathrm{E}-03 \\
{[5.86 \mathrm{e}-04]}\end{array}$ & $\begin{array}{l}-3.00 \mathrm{E}-03 \\
{[2.87 \mathrm{e}-04]}\end{array}$ \\
\hline $\begin{array}{l}\text { Ground Temperature } \\
{ }^{*} \text { Inc } 2574\end{array}$ & $\begin{array}{l}-1.00 \mathrm{E}-03 \\
{[1.37 \mathrm{e}-04]}\end{array}$ & $\begin{array}{c}3.20 \mathrm{E}-04 \\
{[2.37 \mathrm{e}-04]}\end{array}$ & $\begin{array}{l}-1.03 \mathrm{E}-03 \\
{[3.54 \mathrm{e}-04]}\end{array}$ & $\begin{array}{l}-6.79 \mathrm{E}-04 \\
{[1.67 \mathrm{e}-04]}\end{array}$ \\
\hline $\begin{array}{l}\text { Ground Temperature } \\
* \text { Inc75 }\end{array}$ & $\begin{array}{l}-1.26 \mathrm{E}-03 \\
{[1.44 \mathrm{e}-04]}\end{array}$ & $\begin{array}{l}9.14 \mathrm{E}-04 \\
{[2.45 \mathrm{e}-04]}\end{array}$ & $\begin{array}{l}-1.46 \mathrm{E}-03 \\
{[3.65 \mathrm{e}-04]}\end{array}$ & $\begin{array}{l}-4.21 \mathrm{E}-04 \\
{[1.75 \mathrm{e}-04]}\end{array}$ \\
\hline $\begin{array}{l}\text { Income in } 25 \text { th to } \\
\text { 74th Percentile Range }\end{array}$ & $\begin{array}{c}4.12 \mathrm{E}-01 \\
{[7.35 \mathrm{e}-03]}\end{array}$ & $\begin{array}{c}4.21 \mathrm{E}-01 \\
{[1.27 \mathrm{e}-02]}\end{array}$ & $\begin{array}{l}3.50 \mathrm{E}-01 \\
{[1.90 \mathrm{e}-02]}\end{array}$ & $\begin{array}{c}2.31 \mathrm{E}-01 \\
{[9.02 \mathrm{e}-03]}\end{array}$ \\
\hline $\begin{array}{l}\text { Income in } 75 \text { th or } \\
\text { above Percentile Range }\end{array}$ & $\begin{array}{l}7.21 \mathrm{E}-01 \\
{[7.74 \mathrm{e}-03]}\end{array}$ & $\begin{array}{c}9.13 \mathrm{E}-01 \\
{[1.32 \mathrm{e}-02]}\end{array}$ & $\begin{array}{c}8.38 \mathrm{E}-01 \\
{[1.95 \mathrm{e}-02]}\end{array}$ & $\begin{array}{c}5.13 \mathrm{E}-01 \\
{[9.40 \mathrm{e}-03]}\end{array}$ \\
\hline Constant & $\begin{array}{c}4.68 \mathrm{E}+00 \\
{[1.70 \mathrm{e}-02]}\end{array}$ & $\begin{array}{c}3.45 \mathrm{E}+00 \\
{[2.78 \mathrm{e}-02]}\end{array}$ & $\begin{array}{l}3.40 \mathrm{E}+00 \\
{[2.23 \mathrm{e}-02]}\end{array}$ & $\begin{array}{c}3.98 \mathrm{E}+00 \\
{[2.02 \mathrm{e}-02]}\end{array}$ \\
\hline State and Year & No & No & No & No \\
\hline State*Year and Month & Yes & Yes & Yes & Yes \\
\hline R-squared & 0.1095 & 0.108 & 0.0864 & 0.0829 \\
\hline $\mathrm{N}$ & 606744 & 508311 & 335142 & 528093 \\
\hline
\end{tabular}


Table 6: Results for July and August in Southern Regions (Cool or Eat)

\begin{tabular}{|c|c|c|c|c|}
\hline & $\begin{array}{l}\text { Food In the } \\
\text { Home }\end{array}$ & $\begin{array}{l}\text { Food Out of } \\
\text { Home }\end{array}$ & Clothing & Home Fuel \\
\hline Ground Temperature & $\begin{array}{c}1.35 \mathrm{E}-02 \\
{[3.04 \mathrm{e}-03]}\end{array}$ & $\begin{array}{l}-4.49 \mathrm{E}-04 \\
{[5.54 \mathrm{e}-03]}\end{array}$ & $\begin{array}{l}-5.66 \mathrm{E}-02 \\
{[8.16 \mathrm{e}-03]}\end{array}$ & $\begin{array}{l}-2.23 \mathrm{E}-03 \\
{[3.22 \mathrm{e}-03]}\end{array}$ \\
\hline $\begin{array}{l}\text { Ground Temperature } \\
{ }_{*}^{*} \text { Inc } 2574\end{array}$ & $\begin{array}{l}-1.06 \mathrm{E}-02 \\
{[2.59 \mathrm{e}-03]}\end{array}$ & $\begin{array}{c}6.37 \mathrm{E}-03 \\
{[4.78 \mathrm{e}-03]}\end{array}$ & $\begin{array}{c}1.97 \mathrm{E}-02 \\
{[7.05 \mathrm{e}-03]}\end{array}$ & $\begin{array}{c}8.48 \mathrm{E}-03 \\
{[2.81 \mathrm{e}-03]}\end{array}$ \\
\hline $\begin{array}{l}\text { Ground Temperature } \\
\text { *Inc75 }\end{array}$ & $\begin{array}{l}-1.78 \mathrm{E}-02 \\
{[2.75 \mathrm{e}-03]}\end{array}$ & $\begin{array}{l}-3.24 \mathrm{E}-03 \\
{[4.97 \mathrm{e}-03]}\end{array}$ & $\begin{array}{c}1.61 \mathrm{E}-02 \\
{[7.31 \mathrm{e}-03]}\end{array}$ & $\begin{array}{c}8.84 \mathrm{E}-03 \\
{[2.93 \mathrm{e}-03]}\end{array}$ \\
\hline $\begin{array}{l}\text { Income in } 25 \text { th to } \\
\text { 74th Percentile Range }\end{array}$ & $\begin{array}{l}1.16 \mathrm{E}+00 \\
{[2.07 \mathrm{e}-01]}\end{array}$ & $\begin{array}{l}-7.88 \mathrm{E}-02 \\
{[3.82 \mathrm{e}-01]}\end{array}$ & $\begin{array}{l}-1.30 \mathrm{E}+00 \\
{[5.63 \mathrm{e}-01]}\end{array}$ & $\begin{array}{l}-4.49 \mathrm{E}-01 \\
{[2.25 \mathrm{e}-01]}\end{array}$ \\
\hline $\begin{array}{l}\text { Income in } 75 \text { th or } \\
\text { above Percentile Range }\end{array}$ & $\begin{array}{l}2.04 \mathrm{E}+00 \\
{[2.19 \mathrm{e}-01]}\end{array}$ & $\begin{array}{c}1.27 \mathrm{E}+00 \\
{[3.97 \mathrm{e}-01]}\end{array}$ & $\begin{array}{l}-5.35 \mathrm{E}-01 \\
{[5.83 \mathrm{e}-01]}\end{array}$ & $\begin{array}{l}-1.23 \mathrm{E}-01 \\
{[2.35 \mathrm{e}-01]}\end{array}$ \\
\hline Constant & $\begin{array}{l}3.81 \mathrm{E}+00 \\
{[2.47 \mathrm{e}-01]}\end{array}$ & $\begin{array}{l}3.63 \mathrm{E}+00 \\
{[4.48 \mathrm{e}-01]}\end{array}$ & $\begin{array}{c}8.44 \mathrm{E}+00 \\
{[6.61 \mathrm{e}-01]}\end{array}$ & $\begin{array}{l}4.18 \mathrm{E}+00 \\
{[2.61 \mathrm{e}-01]}\end{array}$ \\
\hline State and Year & Yes & Yes & Yes & Yes \\
\hline State*Year and Month & No & No & No & No \\
\hline R-squared & 0.1167 & 0.1133 & 0.0397 & 0.1024 \\
\hline $\mathrm{N}$ & 42803 & 35481 & 23355 & 37855 \\
\hline & $\begin{array}{l}\text { Food In the } \\
\text { Home }\end{array}$ & $\begin{array}{l}\text { Food Out of } \\
\text { Home }\end{array}$ & Clothing & Home Fuel \\
\hline Ground Temperature & $\begin{array}{c}5.59 \mathrm{E}-03 \\
{[3.95 \mathrm{e}-03]}\end{array}$ & $\begin{array}{c}2.46 \mathrm{E}-03 \\
{[7.01 \mathrm{e}-03]}\end{array}$ & $\begin{array}{l}-1.63 \mathrm{E}-02 \\
{[1.03 \mathrm{e}-02]}\end{array}$ & $\begin{array}{c}5.21 \mathrm{E}-05 \\
{[4.10 \mathrm{e}-03]}\end{array}$ \\
\hline $\begin{array}{l}\text { Ground Temperature } \\
\text { *Inc } 2574\end{array}$ & $\begin{array}{l}-8.37 \mathrm{E}-03 \\
{[2.61 \mathrm{e}-03]}\end{array}$ & $\begin{array}{c}3.82 \mathrm{E}-03 \\
{[4.83 \mathrm{e}-03]}\end{array}$ & $\begin{array}{c}1.89 \mathrm{E}-02 \\
{[7.12 \mathrm{e}-03]}\end{array}$ & $\begin{array}{c}8.37 \mathrm{E}-03 \\
{[2.81 \mathrm{e}-03]}\end{array}$ \\
\hline $\begin{array}{l}\text { Ground Temperature } \\
\text { *Inc } 75^{\text {Int }}\end{array}$ & $\begin{array}{l}-1.55 \mathrm{E}-02 \\
{[2.77 \mathrm{e}-03]}\end{array}$ & $\begin{array}{l}-4.27 \mathrm{E}-03 \\
{[5.02 \mathrm{e}-03]}\end{array}$ & $\begin{array}{c}1.45 \mathrm{E}-02 \\
{[7.38 \mathrm{e}-03]}\end{array}$ & $\begin{array}{c}9.83 \mathrm{E}-03 \\
{[2.93 \mathrm{e}-03]}\end{array}$ \\
\hline $\begin{array}{l}\text { Income in 25th to } \\
\text { 74th Percentile Range }\end{array}$ & $\begin{array}{l}9.79 \mathrm{E}-01 \\
{[2.09 \mathrm{e}-01]}\end{array}$ & $\begin{array}{c}1.35 \mathrm{E}-01 \\
{[3.86 \mathrm{e}-01]}\end{array}$ & $\begin{array}{l}-1.23 \mathrm{E}+00 \\
{[5.69 \mathrm{e}-01]}\end{array}$ & $\begin{array}{l}-4.37 \mathrm{E}-01 \\
{[2.25 \mathrm{e}-01]}\end{array}$ \\
\hline $\begin{array}{l}\text { Income in } 75 \text { th or } \\
\text { above Percentile Range }\end{array}$ & $\begin{array}{l}1.86 \mathrm{E}+00 \\
{[2.21 \mathrm{e}-01]}\end{array}$ & $\begin{array}{c}1.36 \mathrm{E}+00 \\
{[4.01 \mathrm{e}-01]}\end{array}$ & $\begin{array}{l}-4.07 \mathrm{E}-01 \\
{[5.90 \mathrm{e}-01]}\end{array}$ & $\begin{array}{c}-2.01 \mathrm{E}-01 \\
{[2.35 \mathrm{e}-01]}\end{array}$ \\
\hline Constant & $\begin{array}{c}4.24 \mathrm{E}+00 \\
{[3.13 \mathrm{e}-01]}\end{array}$ & $\begin{array}{c}3.26 \mathrm{E}+00 \\
{[5.56 \mathrm{e}-01]}\end{array}$ & $\begin{array}{c}5.16 \mathrm{E}+00 \\
{[8.14 \mathrm{e}-01]}\end{array}$ & $\begin{array}{c}3.99 \mathrm{E}+00 \\
{[3.30 \mathrm{e}-01]}\end{array}$ \\
\hline State and Year & No & No & No & No \\
\hline State*Year and Month & Yes & Yes & Yes & Yes \\
\hline R-squared & 0.1023 & 0.106 & 0.0547 & 0.1005 \\
\hline $\mathrm{N}$ & 42803 & 35481 & 23355 & 37855 \\
\hline
\end{tabular}


Table 7: Results for Lagged Temperature: All Regions

\begin{tabular}{|c|c|c|c|c|}
\hline & $\begin{array}{l}\text { Food In the } \\
\text { Home }\end{array}$ & $\begin{array}{l}\text { Food Out of } \\
\text { Home }\end{array}$ & Clothing & Home Fuel \\
\hline Ground Temperature & $\begin{array}{c}2.23 \mathrm{E}-03 \\
{[9.61 \mathrm{e}-05]}\end{array}$ & $\begin{array}{c}1.60 \mathrm{E}-03 \\
{[1.73 \mathrm{e}-04]}\end{array}$ & $\begin{array}{l}-3.34 \mathrm{E}-03 \\
{[2.61 \mathrm{e}-04]}\end{array}$ & $\begin{array}{l}-5.21 \mathrm{E}-03 \\
{[1.17 \mathrm{e}-04]}\end{array}$ \\
\hline $\begin{array}{l}\text { Ground Temperature } \\
\text { *Inc2574 }\end{array}$ & $\begin{array}{l}-1.98 \mathrm{E}-03 \\
{[1.14 \mathrm{e}-04]}\end{array}$ & $\begin{array}{l}9.77 \mathrm{E}-05 \\
{[1.99 \mathrm{e}-04]}\end{array}$ & $\begin{array}{l}-6.60 \mathrm{E}-04 \\
{[2.98 \mathrm{e}-04]}\end{array}$ & $\begin{array}{l}-4.68 \mathrm{E}-04 \\
{[1.35 \mathrm{e}-04]}\end{array}$ \\
\hline $\begin{array}{l}\text { Ground Temperature } \\
\text { *Inc75 }\end{array}$ & $\begin{array}{l}-2.22 \mathrm{E}-03 \\
{[1.21 \mathrm{e}-04]}\end{array}$ & $\begin{array}{l}7.14 \mathrm{E}-04 \\
{[2.07 \mathrm{e}-04]}\end{array}$ & $\begin{array}{l}-1.03 \mathrm{E}-03 \\
{[3.09 \mathrm{e}-04]}\end{array}$ & $\begin{array}{l}-7.88 \mathrm{E}-05 \\
{[1.42 \mathrm{e}-04]}\end{array}$ \\
\hline $\begin{array}{l}\text { Income in } 25 \text { th to } \\
\text { 74th Percentile Range }\end{array}$ & $\begin{array}{c}4.53 \mathrm{E}-01 \\
{[6.55 \mathrm{e}-03]}\end{array}$ & $\begin{array}{c}4.33 \mathrm{E}-01 \\
{[1.14 \mathrm{e}-02]}\end{array}$ & $\begin{array}{c}3.34 \mathrm{E}-01 \\
{[1.70 \mathrm{e}-02]}\end{array}$ & $\begin{array}{l}2.17 \mathrm{E}-01 \\
{[7.81 \mathrm{e}-03]}\end{array}$ \\
\hline $\begin{array}{l}\text { Income in } 75 \text { th or } \\
\text { above Percentile Range }\end{array}$ & $\begin{array}{c}7.67 \mathrm{E}-01 \\
{[6.91 \mathrm{e}-03]}\end{array}$ & $\begin{array}{c}9.32 \mathrm{E}-01 \\
{[1.18 \mathrm{e}-02]}\end{array}$ & $\begin{array}{c}8.30 \mathrm{E}-01 \\
{[1.76 \mathrm{e}-02]}\end{array}$ & $\begin{array}{c}4.98 \mathrm{E}-01 \\
{[8.17 \mathrm{e}-03]}\end{array}$ \\
\hline Constant & $\begin{array}{l}4.77 \mathrm{E}+00 \\
{[6.33 \mathrm{e}-03]}\end{array}$ & $\begin{array}{l}3.40 \mathrm{E}+00 \\
{[1.12 \mathrm{e}-02]}\end{array}$ & $\begin{array}{l}3.94 \mathrm{E}+00 \\
{[1.66 \mathrm{e}-02]}\end{array}$ & $\begin{array}{l}4.20 \mathrm{E}+00 \\
{[7.66 \mathrm{e}-03]}\end{array}$ \\
\hline State and Year & Yes & Yes & Yes & Yes \\
\hline State*Year and Month & No & No & No & No \\
\hline R-squared & 0.1181 & 0.1135 & 0.0577 & 0.0706 \\
\hline $\mathrm{N}$ & 853307 & 711646 & 469543 & 747005 \\
\hline & $\begin{array}{l}\text { Food In the } \\
\text { Home }\end{array}$ & $\begin{array}{l}\text { Food Out of } \\
\text { Home }\end{array}$ & Clothing & Home Fuel \\
\hline Ground Temperature & $\begin{array}{c}1.23 \mathrm{E}-03 \\
{[2.02 \mathrm{e}-04]}\end{array}$ & $\begin{array}{l}9.22 \mathrm{E}-05 \\
{[3.36 \mathrm{e}-04]}\end{array}$ & $\begin{array}{l}-1.24 \mathrm{E}-03 \\
{[4.93 \mathrm{e}-04]}\end{array}$ & $\begin{array}{l}-5.29 \mathrm{E}-03 \\
{[2.32 \mathrm{e}-04]}\end{array}$ \\
\hline $\begin{array}{l}\text { Ground Temperature } \\
\text { *Inc } 2574\end{array}$ & $\begin{array}{l}-1.93 \mathrm{E}-03 \\
{[1.14 \mathrm{e}-04]}\end{array}$ & $\begin{array}{c}1.08 \mathrm{E}-04 \\
{[1.99 \mathrm{e}-04]}\end{array}$ & $\begin{array}{l}-8.63 \mathrm{E}-04 \\
{[2.94 \mathrm{e}-04]}\end{array}$ & $\begin{array}{l}-3.61 \mathrm{E}-04 \\
{[1.34 \mathrm{e}-04]}\end{array}$ \\
\hline $\begin{array}{l}\text { Ground Temperature } \\
* \text { Inc75 }\end{array}$ & $\begin{array}{l}-2.14 \mathrm{E}-03 \\
{[1.21 \mathrm{e}-04]}\end{array}$ & $\begin{array}{c}7.38 \mathrm{E}-04 \\
{[2.07 \mathrm{e}-04]}\end{array}$ & $\begin{array}{l}-1.27 \mathrm{E}-03 \\
{[3.04 \mathrm{e}-04]}\end{array}$ & $\begin{array}{l}-3.21 \mathrm{E}-05 \\
{[1.41 \mathrm{e}-04]}\end{array}$ \\
\hline $\begin{array}{l}\text { Income in } 25 \text { th to } \\
\text { 74th Percentile Range }\end{array}$ & $\begin{array}{c}4.50 \mathrm{E}-01 \\
{[6.53 \mathrm{e}-03]}\end{array}$ & $\begin{array}{c}4.34 \mathrm{E}-01 \\
{[1.14 \mathrm{e}-02]}\end{array}$ & $\begin{array}{c}3.51 \mathrm{E}-01 \\
{[1.67 \mathrm{e}-02]}\end{array}$ & $\begin{array}{l}2.10 \mathrm{E}-01 \\
{[7.74 \mathrm{e}-03]}\end{array}$ \\
\hline $\begin{array}{l}\text { Income in } 75 \text { th or } \\
\text { above Percentile Range }\end{array}$ & $\begin{array}{l}7.61 \mathrm{E}-01 \\
{[6.90 \mathrm{e}-03]}\end{array}$ & $\begin{array}{c}9.30 \mathrm{E}-01 \\
{[1.18 \mathrm{e}-02]}\end{array}$ & $\begin{array}{c}8.48 \mathrm{E}-01 \\
{[1.73 \mathrm{e}-02]}\end{array}$ & $\begin{array}{c}4.96 \mathrm{E}-01 \\
{[8.09 \mathrm{e}-03]}\end{array}$ \\
\hline Constant & $\begin{array}{c}4.62 \mathrm{E}+00 \\
{[8.21 \mathrm{e}-03]}\end{array}$ & $\begin{array}{l}3.36 \mathrm{E}+00 \\
{[1.40 \mathrm{e}-02]}\end{array}$ & $\begin{array}{c}3.76 \mathrm{E}+00 \\
{[2.14 \mathrm{e}-02]}\end{array}$ & $\begin{array}{l}4.19 \mathrm{E}+00 \\
{[9.62 \mathrm{e}-03]}\end{array}$ \\
\hline State and Year & No & No & No & No \\
\hline State*Year and Month & Yes & Yes & Yes & Yes \\
\hline R-squared & 0.1074 & 0.1084 & 0.0861 & 0.0747 \\
\hline $\mathrm{N}$ & 853307 & 711646 & 469543 & 747005 \\
\hline
\end{tabular}


Table 8: Nutritional Outcomes in Winter and Fall

\begin{tabular}{|c|c|c|c|c|c|c|c|}
\hline & & \multicolumn{3}{|c|}{ Poor Families $^{\mathrm{a}}$} & \multicolumn{3}{|c|}{ Richer Families $^{b}$} \\
\hline Group & Nutritional Outcomes & Fall & Winter & Difference & Fall & Winter & Difference \\
\hline \multirow{5}{*}{$\begin{array}{c}\text { All } \\
\text { Adults, } \\
\mathrm{N}=5,500\end{array}$} & Dietary Quality $^{\mathrm{c}}$ & 59.1 & 60.1 & 1.0 & 64.6 & 65.0 & 0.4 \\
\hline & Serum Measures & & & & & & \\
\hline & Anemia & 0.098 & 0.097 & -0.001 & 0.085 & 0.101 & 0.016 \\
\hline & Low A, C, or E & 0.198 & 0.215 & 0.017 & 0.094 & 0.098 & 0.004 \\
\hline & Calories & 1741.0 & 1743.9 & 2.9 & 1928.8 & 1847.8 & $-81.0^{*}$ \\
\hline \multirow{5}{*}{$\begin{array}{c}\text { Adults } \\
\text { with } \\
\text { children, } \\
\mathrm{N}=2,357\end{array}$} & Dietary Quality $^{\mathrm{c}}$ & 56.2 & 56.6 & 0.4 & 61.1 & 61.6 & 0.5 \\
\hline & Serum Measures & & & & & & \\
\hline & Anemia & 0.091 & 0.084 & -0.007 & 0.093 & 0.089 & -0.003 \\
\hline & Low $A, C$, or $E$ & 0.135 & 0.174 & 0.039 & 0.015 & 0.051 & 0.037 \\
\hline & Calories & 1977.0 & 1881.4 & -95.6 & 2210.7 & 1974.0 & $-236.7^{* * *}$ \\
\hline \multirow{5}{*}{$\begin{array}{l}\text { Children, } \\
\mathrm{N}=4,496\end{array}$} & Dietary Quality $^{\mathrm{c}}$ & 62.9 & 63.0 & 0.1 & 66.6 & 64.6 & $-2.0^{* * *}$ \\
\hline & Serum Measures & & & & & & \\
\hline & Anemia & 0.001 & 0.020 & 0.019 & 0.039 & 0.023 & $-0.016^{* *}$ \\
\hline & Low $\mathrm{A}, \mathrm{C}$, or $\mathrm{E}$ & 0.116 & 0.139 & 0.023 & 0.082 & 0.081 & -0.001 \\
\hline & Calories & 1608.1 & 1647.1 & 38.9 & 1624.7 & 1718.9 & $94.2^{*}$ \\
\hline
\end{tabular}

Source: Authors' tabulations from the NHANES.

Notes: These outcomes are based on a regression analysis in which we estimate separate models for each outcome and age (children and adults). In addition to the key independent variables of income levels and season of interview, the regressions include race dummies, a quadratic in age, eight region dummies, and a gender dummy. The results from these regressions are shown in Appendix Tables 3a-3c. The outcomes are the predicted outcome for a standardized person (a white female from the urban Northeast); the age of the child is 8 and the age of the adult is 35 . The statistical tests are based on the coefficients of the regression, according to the following levels: * for 0.05 and $* *$ for 0.01 . The only statistically significant difference between adults and children is for rich families in dietary quality $(\alpha<0.05)$.

${ }^{a}$ Poor families have a poverty-income ratio less than 1.5 .

${ }^{\mathrm{b}}$ Richer families have a poverty-income ratio greater than 3 .

${ }^{\mathrm{c}}$ Dietary quality is measured using the Health Eating Index (on a scale from 0 to 100) — see text for an explanation. 
Table 9: Nutritional Outcomes in Winter and Spring

\begin{tabular}{|c|c|c|c|c|c|c|c|}
\hline & & \multicolumn{3}{|c|}{ Poor Families $^{\mathrm{a}}$} & \multicolumn{3}{|c|}{ Richer Families $^{\text {b }}$} \\
\hline Group & Nutritional Outcomes & Spring & Winter & Difference & Spring & Winter & Difference \\
\hline \multirow{5}{*}{$\begin{array}{c}\text { All } \\
\text { Adults, } \\
\mathrm{N}=5,609\end{array}$} & Dietary Quality $^{\mathrm{c}}$ & 62.4 & 61.1 & $-1.3^{* *}$ & 65.5 & 65.2 & -0.3 \\
\hline & Serum Measures & & & & & & \\
\hline & Anemia & 0.067 & 0.076 & 0.009 & 0.056 & 0.088 & $0.033^{* * *}$ \\
\hline & Low $A, C$, or $E$ & 0.140 & 0.204 & $0.064^{* * *}$ & 0.038 & 0.093 & $0.055^{* * *}$ \\
\hline & Calories & 2001.8 & 1841.3 & $-160.5^{* * *}$ & 2011.2 & 1920.6 & $-90.6^{* *}$ \\
\hline \multirow{5}{*}{$\begin{array}{c}\text { Adults } \\
\text { with } \\
\text { children, } \\
\mathrm{N}=2,406\end{array}$} & Dietary Quality $^{\mathrm{c}}$ & 60.9 & 58.1 & $-2.8^{* * *}$ & 62.9 & 62.0 & -1.0 \\
\hline & Serum Measures & & & & & & \\
\hline & Anemia & 0.102 & 0.087 & -0.015 & 0.103 & 0.094 & -0.010 \\
\hline & Low $A, C$, or $E$ & 0.143 & 0.207 & $0.064^{* *}$ & 0.045 & 0.067 & 0.022 \\
\hline & Calories & 2049.5 & 1931.1 & $-118.4^{*}$ & 1969.4 & 1992.2 & 22.8 \\
\hline \multirow{5}{*}{$\begin{array}{l}\text { Children, } \\
\mathrm{N}=4,687\end{array}$} & Dietary Quality $^{\mathrm{c}}$ & 66.3 & 65.5 & -0.8 & 69.2 & 66.8 & $-2.4^{* * *}$ \\
\hline & Serum Measures & & & & & & \\
\hline & Anemia & 0.029 & 0.028 & 0.0 & 0.025 & 0.033 & 0.007 \\
\hline & Low $A, C$, or $E$ & 0.159 & 0.134 & 0.0 & 0.105 & 0.068 & -0.037 \\
\hline & Calories & 1663.2 & 1518.2 & $-144.9^{\text {**** }}$ & 1707.8 & 1647.4 & -60.4 \\
\hline
\end{tabular}

Source: Authors' tabulations from the NHANES.

Notes: These outcomes are based on a regression analysis in which we estimate separate models for each outcome and age (children and adults). In addition to the key independent variables of income levels and season of interview, the regressions include race dummies, a quadratic in age, eight region dummies, and a gender dummy. The results from these regressions are shown in Appendix Tables $2 \mathrm{a}-2 \mathrm{c}$. The outcomes are the predicted outcome for a standardized person (a white female from the urban Northeast); the age of the child is 8 and the age of the adult is 35 . The statistical tests are based on the coefficients of the regression, according to the following levels: * for 0.05 and $* *$ for 0.01 . The only statistically significant difference between adults and children is for rich families in dietary quality $(\alpha<0.05)$.

${ }^{a}$ Poor families have a poverty-income ratio less than 1.5 .

${ }^{\mathrm{b}}$ Richer families have a poverty-income ratio greater than 3 .

${ }^{\mathrm{c}}$ Dietary quality is measured using the Health Eating Index (on a scale from 0 to 100) — see text for an explanation. 
Table 10: Nutritional Outcomes in Winter and Summer (Excluding Southern Households)

\begin{tabular}{|c|c|c|c|c|c|c|c|}
\hline & & \multicolumn{3}{|c|}{ Poor Families $^{\mathrm{a}}$} & \multicolumn{3}{|c|}{ Richer Families $^{b}$} \\
\hline Group & Nutritional Outcomes & Summer & Winter & Difference & Summer & Winter & Difference \\
\hline \multirow{5}{*}{$\begin{array}{c}\text { Adults } \\
\text { without } \\
\text { children, } \\
\mathrm{N}=1,762\end{array}$} & Dietary Quality $^{\mathrm{c}}$ & 62.7 & 63.7 & 1.0 & 67.1 & 65.2 & -1.9 \\
\hline & Serum Measures & & & & & & \\
\hline & Anemia & 0.029 & 0.061 & 0.032 & 0.043 & 0.066 & 0.023 \\
\hline & Low $\mathrm{A}, \mathrm{C}$, or $\mathrm{E}$ & 0.239 & 0.134 & $-0.105^{* *}$ & 0.095 & 0.127 & 0.032 \\
\hline & Calories & 2131.8 & 1833.1 & $-298.7^{*}$ & 2162.7 & 1914.3 & $-248.4^{* *}$ \\
\hline \multirow{5}{*}{$\begin{array}{c}\text { Adults } \\
\text { with } \\
\text { children, } \\
\mathrm{N}=1,199\end{array}$} & Dietary Quality $^{c}$ & 59.6 & 58.4 & -1.2 & 64.1 & 63.9 & -0.2 \\
\hline & Serum Measures & & & & & & \\
\hline & Anemia & 0.057 & 0.092 & 0.035 & 0.049 & 0.079 & 0.031 \\
\hline & Low $\mathrm{A}, \mathrm{C}$, or $\mathrm{E}$ & 0.181 & 0.225 & 0.044 & 0.041 & 0.161 & $0.120^{* * * *}$ \\
\hline & Calories & 2473.5 & 2100.0 & $-373.5^{* *}$ & 2372.0 & 2310.3 & -61.7 \\
\hline \multirow{5}{*}{$\begin{array}{l}\text { Children } \\
\mathrm{N}=2,324\end{array}$} & Dietary Quality $^{\mathrm{c}}$ & 64.5 & 61.9 & $-2.6^{*}$ & 66.8 & 62.9 & $-3.9^{* *}$ \\
\hline & Serum Measures & & & & & & \\
\hline & Anemia & 0.010 & 0.032 & 0.022 & 0.005 & 0.040 & 0.035 \\
\hline & Low $\mathrm{A}, \mathrm{C}$, or $\mathrm{E}$ & 0.107 & 0.167 & 0.060 & 0.069 & 0.066 & -0.003 \\
\hline & Calories & 2051.2 & 1758.6 & -292.6 & 1946.4 & 1844.8 & -101.6 \\
\hline
\end{tabular}

Source: Authors' tabulations from the NHANES.

Notes: These outcomes are based on a regression analysis in which we estimate separate models for each outcome and age (children and adults). In addition to the key independent variables of income levels and season of interview, the regressions include race dummies, a quadratic in age, eight region dummies, and a gender dummy. The results from these regressions are shown in Appendix Tables 4a-4c. The outcomes are the predicted outcome for a standardized person (a white female from the urban Northeast); the age of the child is 8 and the age of the adult is 35 . The statistical tests are based on the coefficients of the regression, according to the following levels: * for $0.1, * *$ for 0.05 , and $* * *$ for 0.01 . The only statistically significant difference between adults and children is for rich families in dietary quality $(\alpha<0.05)$.

${ }^{a}$ Poor families have a poverty-income ratio less than 1.5.

${ }^{\mathrm{b}}$ Richer families have a poverty-income ratio greater than 3 .

${ }^{\mathrm{c}}$ Dietary quality is measured using the Health Eating Index (on a scale from 0 to 100 ) — see text for an explanation. 
Table 11: Results for Families with Preschool Children: All Regions

\begin{tabular}{|c|c|c|c|c|}
\hline & $\begin{array}{l}\text { Food In the } \\
\text { Home }\end{array}$ & $\begin{array}{l}\text { Food Out of } \\
\text { Home }\end{array}$ & Clothing & Home Fuel \\
\hline \multirow[t]{2}{*}{ Ground Temperature } & $1.60 \mathrm{E}-03$ & $2.14 \mathrm{E}-03$ & $-1.83 \mathrm{E}-03$ & $-7.32 \mathrm{E}-03$ \\
\hline & {$[1.09 \mathrm{e}-04]$} & {$[2.00 \mathrm{e}-04]$} & [3.15e-04] & [1.37e-04] \\
\hline \multirow{2}{*}{$\begin{array}{l}\text { Ground Temperature } \\
* \text { Inc } 2574\end{array}$} & $-1.49 \mathrm{E}-03$ & 4.91E-04 & $-1.16 \mathrm{E}-03$ & $-9.32 \mathrm{E}-05$ \\
\hline & {$[1.32 \mathrm{e}-04]$} & {$[2.34 \mathrm{e}-04]$} & [3.65e-04] & [1.61e-04] \\
\hline \multirow{2}{*}{$\begin{array}{l}\text { Ground Temperature } \\
* \text { Inc } 75\end{array}$} & $-1.75 \mathrm{E}-03$ & $9.16 \mathrm{E}-04$ & $-1.46 \mathrm{E}-03$ & 4.23E-04 \\
\hline & {$[1.44 \mathrm{e}-04]$} & {$[2.49 \mathrm{e}-04]$} & [3.86e-04] & [1.73e-04] \\
\hline \multirow{2}{*}{$\begin{array}{l}\text { Income in } 25 \text { th to } \\
\text { 74th Percentile Range }\end{array}$} & $4.21 \mathrm{E}-01$ & $4.33 \mathrm{E}-01$ & 3.91E-01 & $1.83 \mathrm{E}-01$ \\
\hline & {$[7.58 \mathrm{e}-03]$} & {$[1.34 \mathrm{e}-02]$} & {$[2.08 \mathrm{e}-02]$} & [9.29e-03] \\
\hline \multirow{2}{*}{$\begin{array}{l}\text { Income in } 75 \text { th or } \\
\text { above Percentile Range }\end{array}$} & $7.21 \mathrm{E}-01$ & $9.11 \mathrm{E}-01$ & $8.71 \mathrm{E}-01$ & $4.48 \mathrm{E}-01$ \\
\hline & {$[8.23 \mathrm{e}-03]$} & {$[1.42 \mathrm{e}-02]$} & {$[2.19 \mathrm{e}-02]$} & [9.95e-03] \\
\hline \multirow[t]{2}{*}{ Constant } & $4.63 \mathrm{E}+00$ & $3.39 \mathrm{E}+00$ & $3.76 \mathrm{E}+00$ & $4.21 \mathrm{E}+00$ \\
\hline & [7.33e-03] & [1.31e-02] & {$[2.02 \mathrm{e}-02]$} & [9.15e-03] \\
\hline State and Year & Yes & Yes & Yes & Yes \\
\hline State*Year and Month & No & No & No & No \\
\hline R-squared & 0.1149 & 0.1091 & 0.0572 & 0.066 \\
\hline \multirow[t]{2}{*}{$\mathrm{N}$} & 584370 & 480296 & 294230 & 504052 \\
\hline & $\begin{array}{l}\text { Food In the } \\
\text { Home }\end{array}$ & $\begin{array}{l}\text { Food Out of } \\
\text { Home }\end{array}$ & Clothing & Home Fuel \\
\hline \multirow[t]{2}{*}{ Ground Temperature } & $1.05 \mathrm{E}-03$ & $-6.27 \mathrm{E}-04$ & $2.05 \mathrm{E}-04$ & $-9.54 \mathrm{E}-03$ \\
\hline & {$[2.41 \mathrm{e}-04]$} & {$[4.07 \mathrm{e}-04]$} & {$[6.22 \mathrm{e}-04]$} & [2.86e-04] \\
\hline \multirow{2}{*}{$\begin{array}{l}\text { Ground Temperature } \\
* \text { Inc2574 }\end{array}$} & $-1.42 \mathrm{E}-03$ & $5.13 \mathrm{E}-04$ & $-1.20 \mathrm{E}-03$ & $-4.11 \mathrm{E}-05$ \\
\hline & {$[1.32 \mathrm{e}-04]$} & {$[2.34 \mathrm{e}-04]$} & [3.60e-04] & {$[1.60 \mathrm{e}-04]$} \\
\hline \multirow{2}{*}{$\begin{array}{l}\text { Ground Temperature } \\
* \text { Inc } 75\end{array}$} & $-1.66 \mathrm{E}-03$ & $9.62 \mathrm{E}-04$ & $-1.56 \mathrm{E}-03$ & $4.16 \mathrm{E}-04$ \\
\hline & {$[1.43 \mathrm{e}-04]$} & {$[2.49 \mathrm{e}-04]$} & [3.81e-04] & {$[1.72 \mathrm{e}-04]$} \\
\hline \multirow{2}{*}{$\begin{array}{l}\text { Income in } 25 \text { th to } \\
\text { 74th Percentile Range }\end{array}$} & $4.16 \mathrm{E}-01$ & $4.33 \mathrm{E}-01$ & $4.00 \mathrm{E}-01$ & $1.80 \mathrm{E}-01$ \\
\hline & {$[7.56 \mathrm{e}-03]$} & {$[1.34 \mathrm{e}-02]$} & {$[2.05 \mathrm{e}-02]$} & [9.22e-03] \\
\hline \multirow{2}{*}{$\begin{array}{l}\text { Income in } 75 \text { th or } \\
\text { above Percentile Range }\end{array}$} & $7.12 \mathrm{E}-01$ & $9.08 \mathrm{E}-01$ & $8.81 \mathrm{E}-01$ & $4.48 \mathrm{E}-01$ \\
\hline & {$[8.20 \mathrm{e}-03]$} & [1.42e-02] & {$[2.16 \mathrm{e}-02]$} & [9.89e-03] \\
\hline \multirow[t]{2}{*}{ Constant } & $4.48 \mathrm{E}+00$ & $3.39 \mathrm{E}+00$ & $3.53 \mathrm{E}+00$ & $4.48 \mathrm{E}+00$ \\
\hline & {$[9.59 \mathrm{e}-03]$} & [1.66e-02] & {$[4.52 \mathrm{e}-02]$} & {$[2.09 \mathrm{e}-02]$} \\
\hline State and Year & No & No & No & No \\
\hline State*Year and Month & Yes & Yes & Yes & Yes \\
\hline R-squared & 0.1033 & 0.103 & 0.0814 & 0.064 \\
\hline $\mathrm{N}$ & 584370 & 480296 & 294230 & 504052 \\
\hline
\end{tabular}


Figure 1: Changes in Expenditures by Category and by Income in Response to an Unseasonable $10^{\circ} \mathrm{F}$ Drop in Temperature

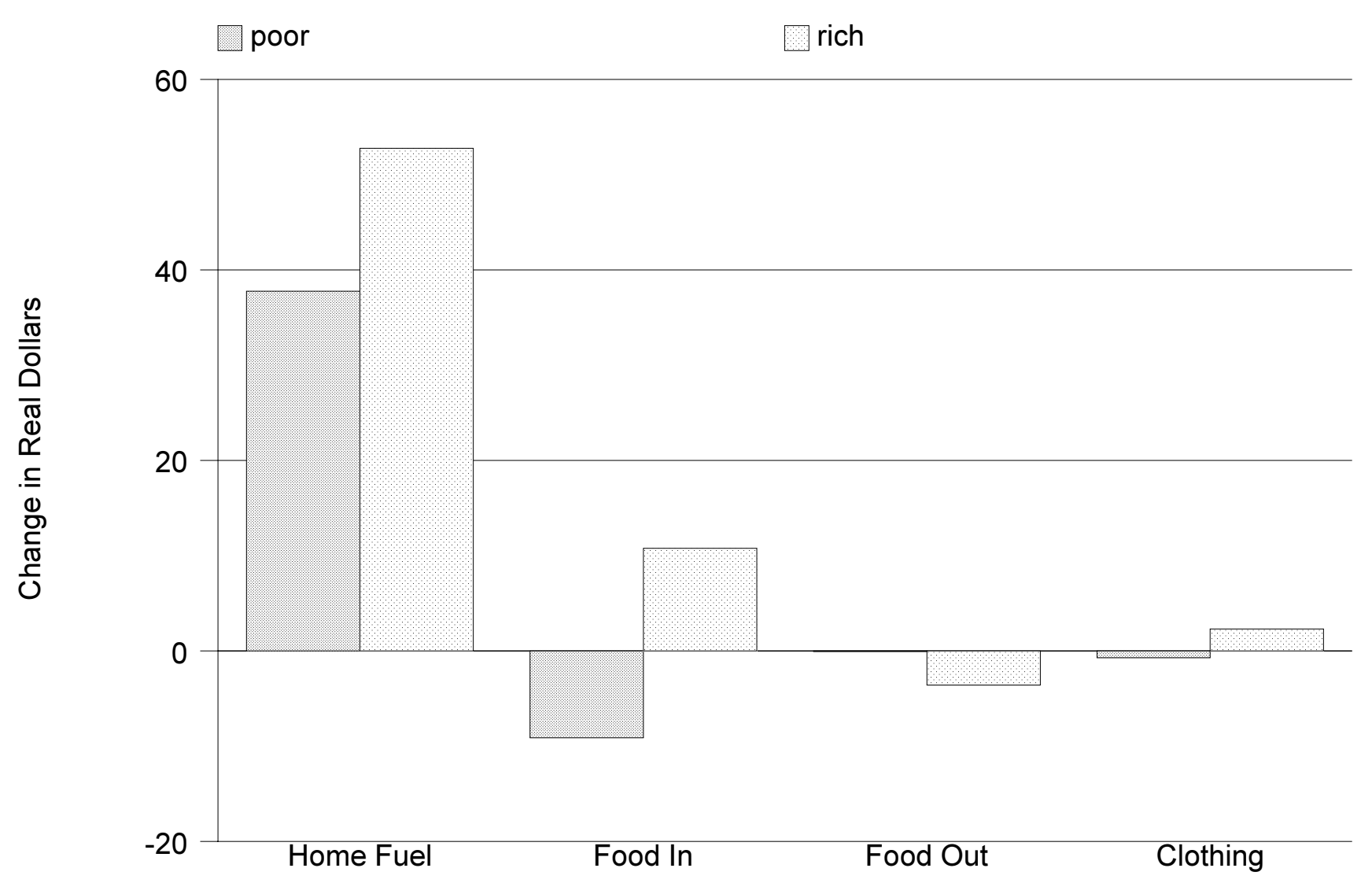

Note: All the differences between poor families and rich families are statistically significant at the $\alpha=0.01$ level. 
Figure 2a: Results for Southern Regions: State and Year Fixed Effects

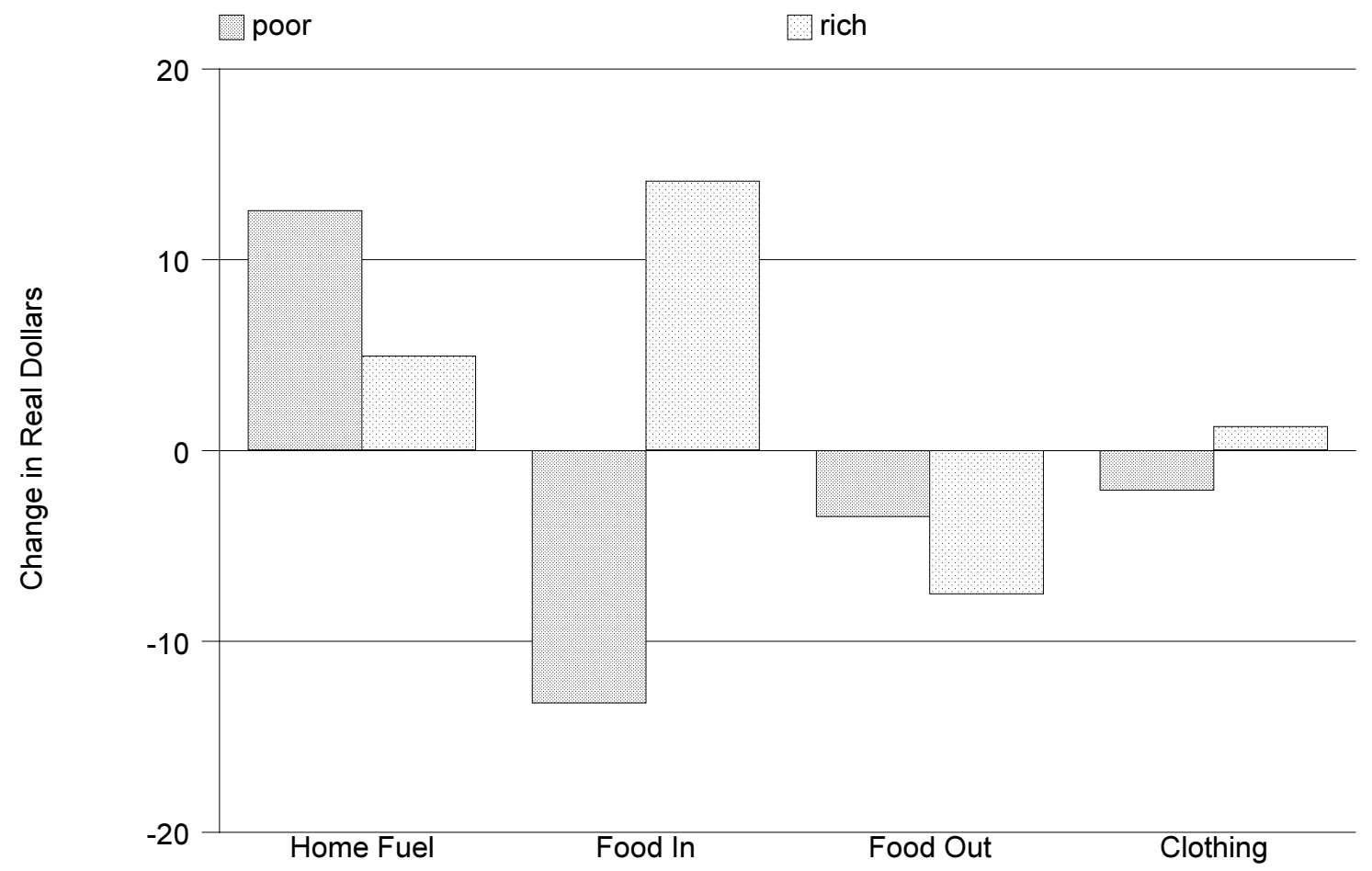

Figure 2b: Results for Southern Regions: State by Year and Month Fixed Effects

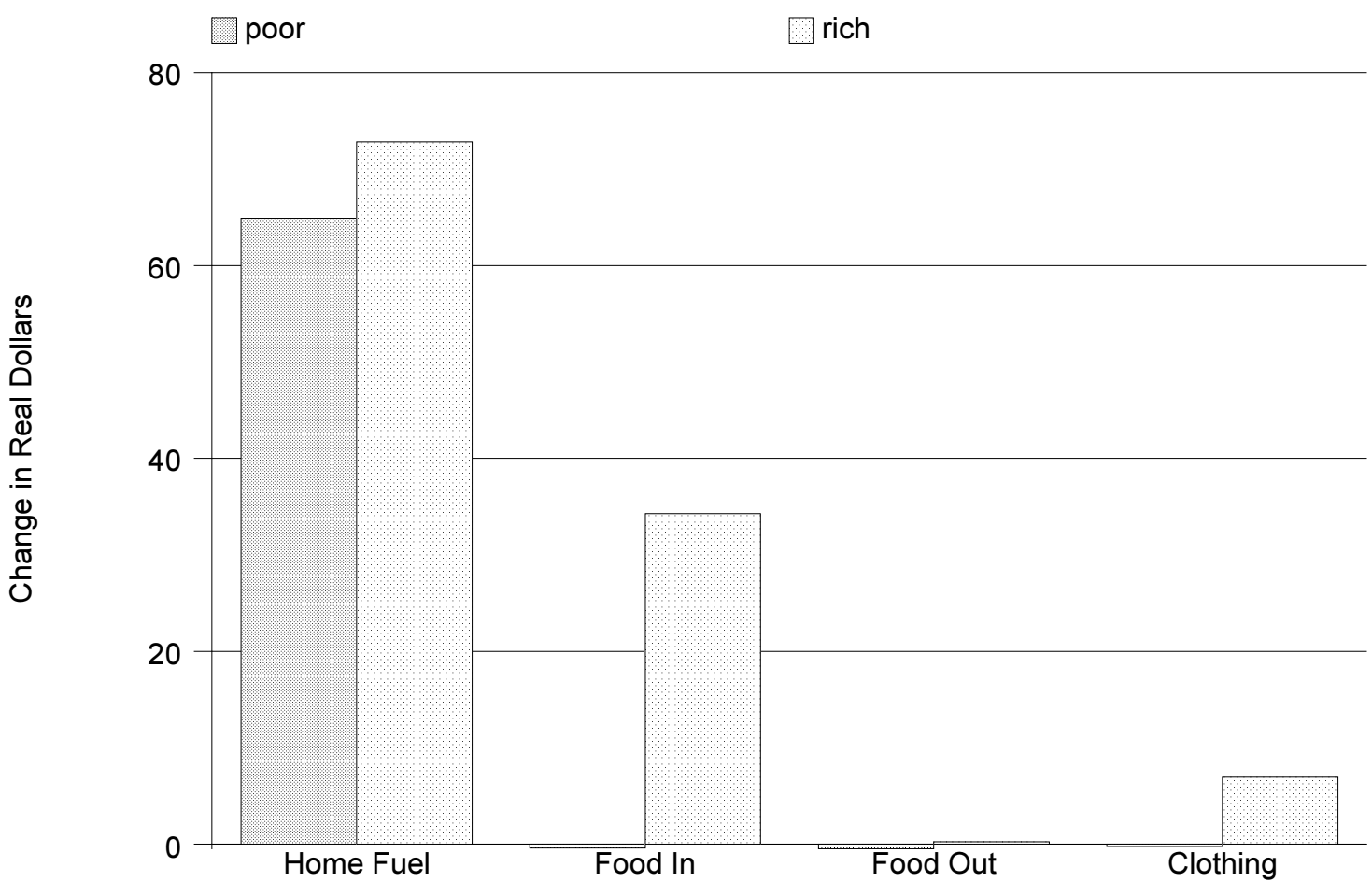


Figure 3a: Results for Non-Southern Regions: State and Year Fixed Effects

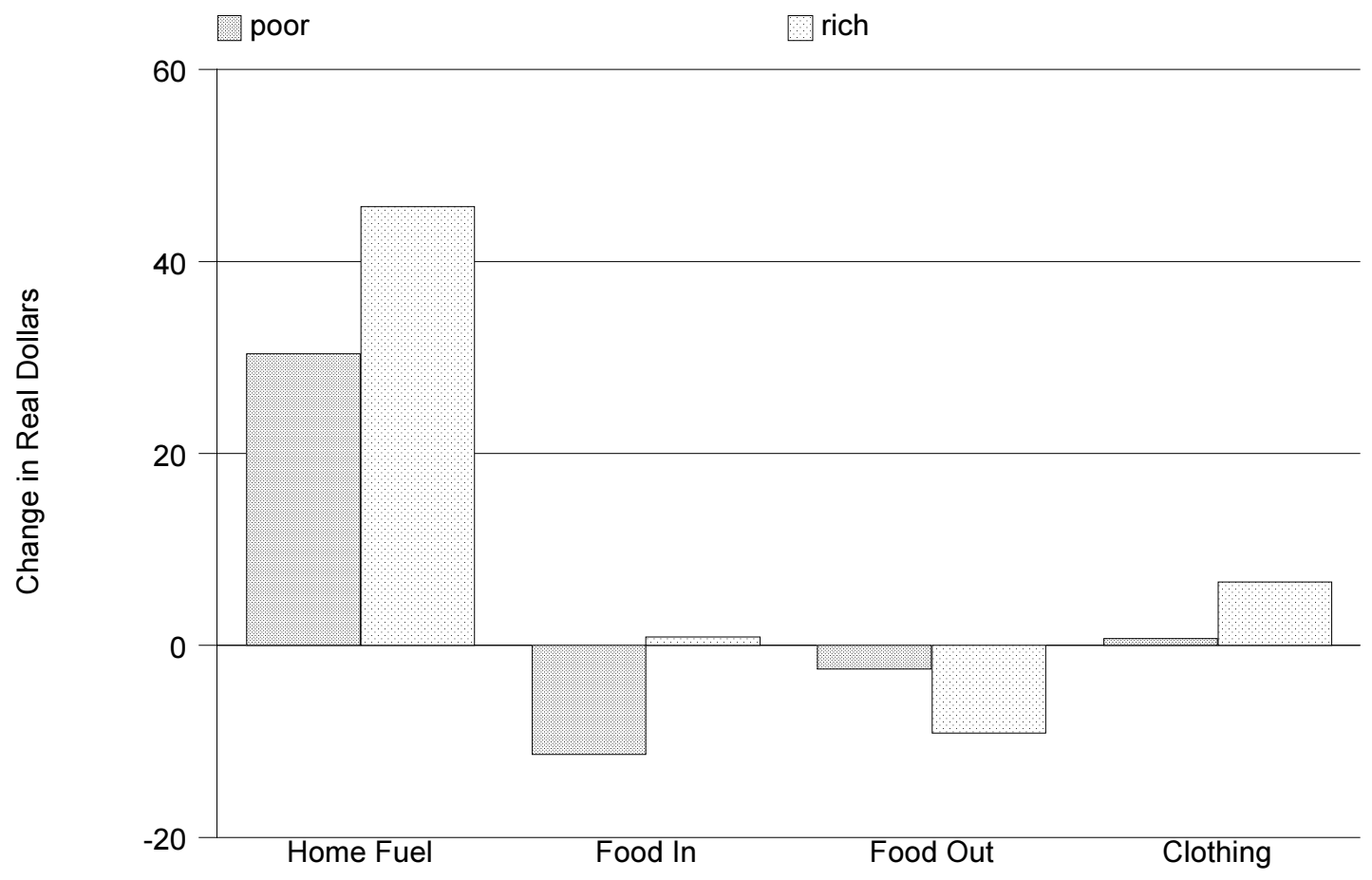

Figure 3b: Results for Non-Southern Regions: State by Year and Month Fixed Effects

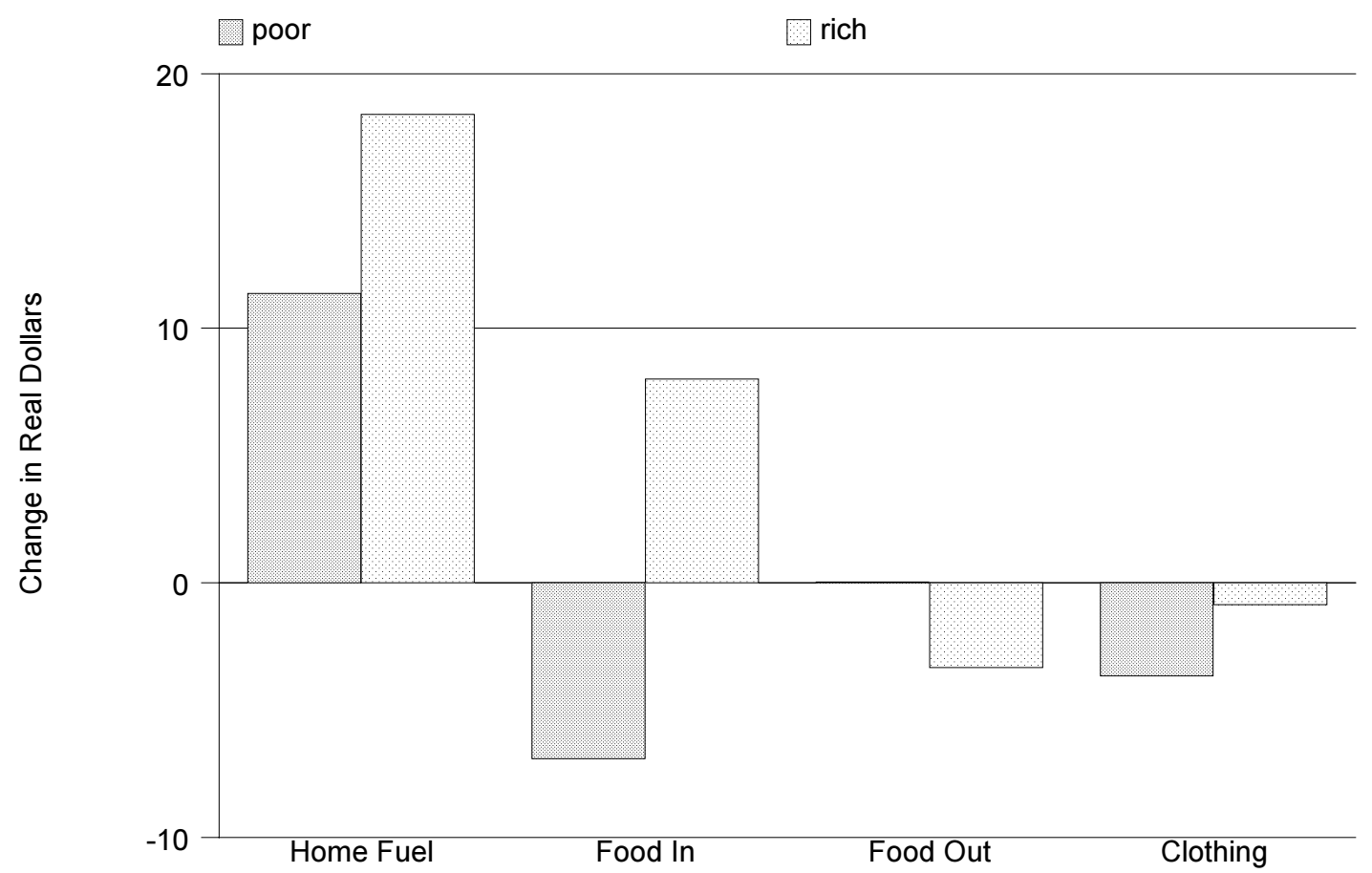


Figure 4a: Results for July and August in Southern Regions (Cool or Eat): State and Year Fixed Effects

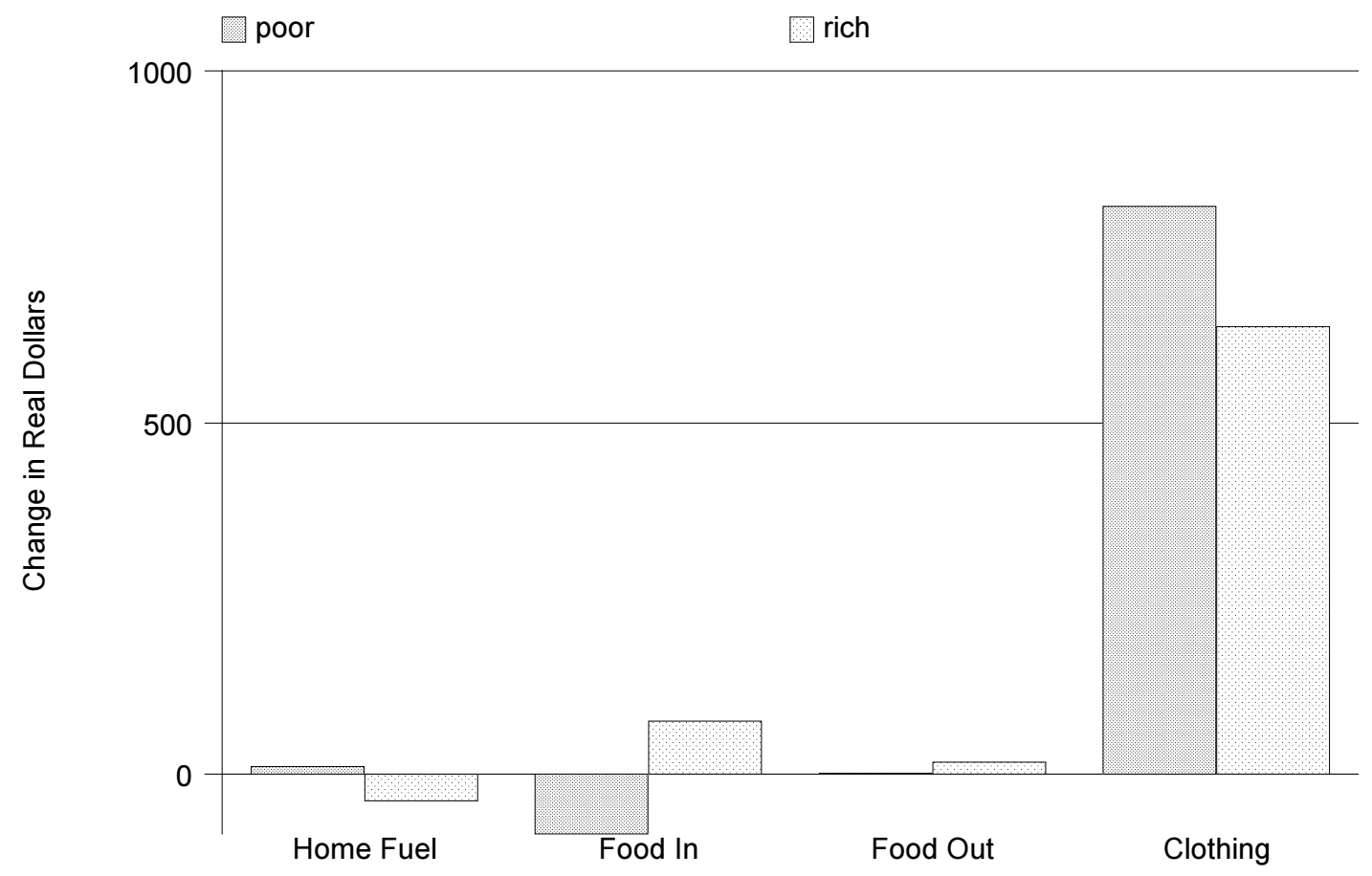

Figure 4b: Results for July and August in Southern Regions (Cool or Eat): State by Year and Month Fixed Effects

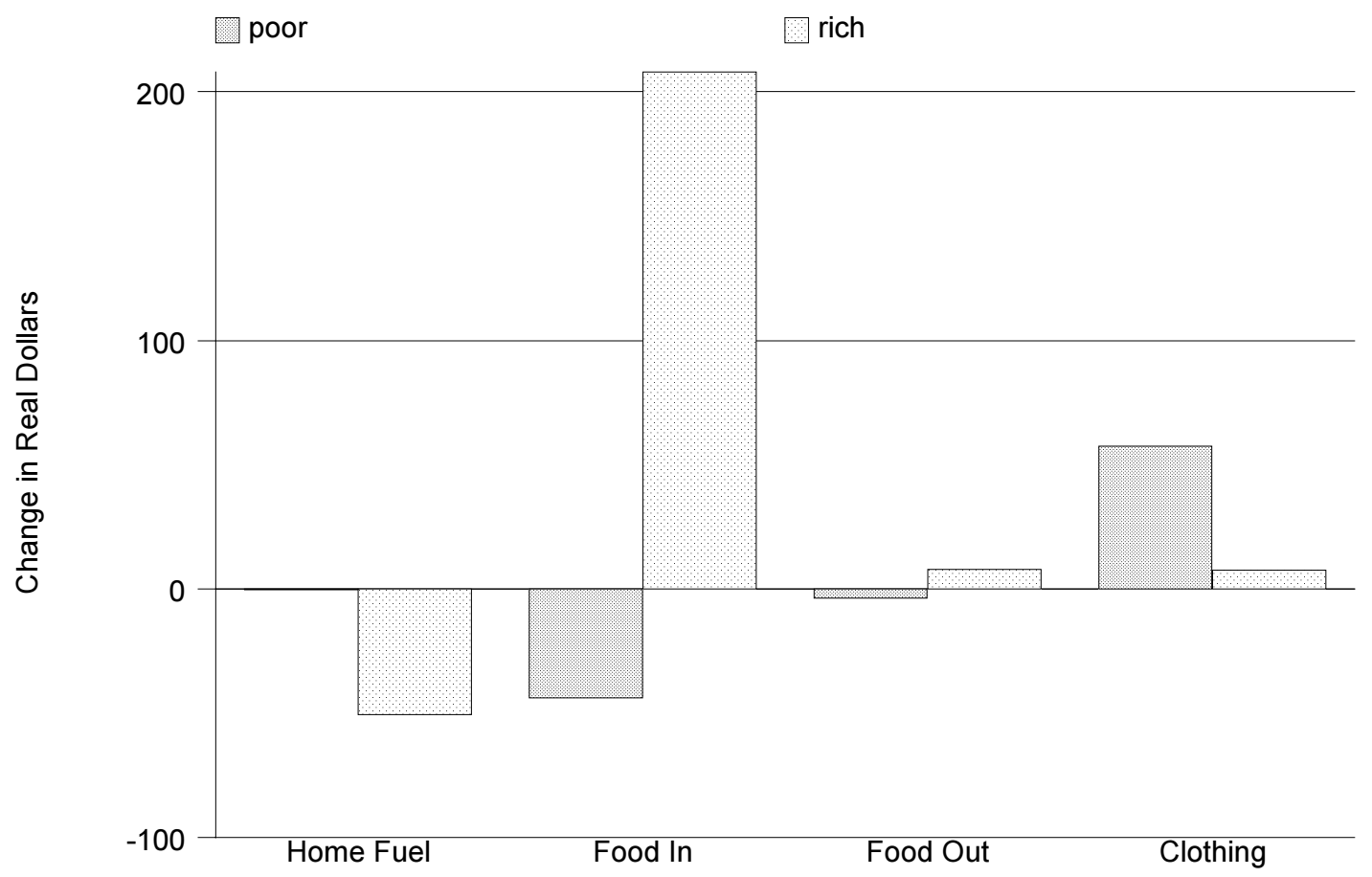


Figure 5a: Results for Lagged Temperature All Regions: State and Year Fixed Effects

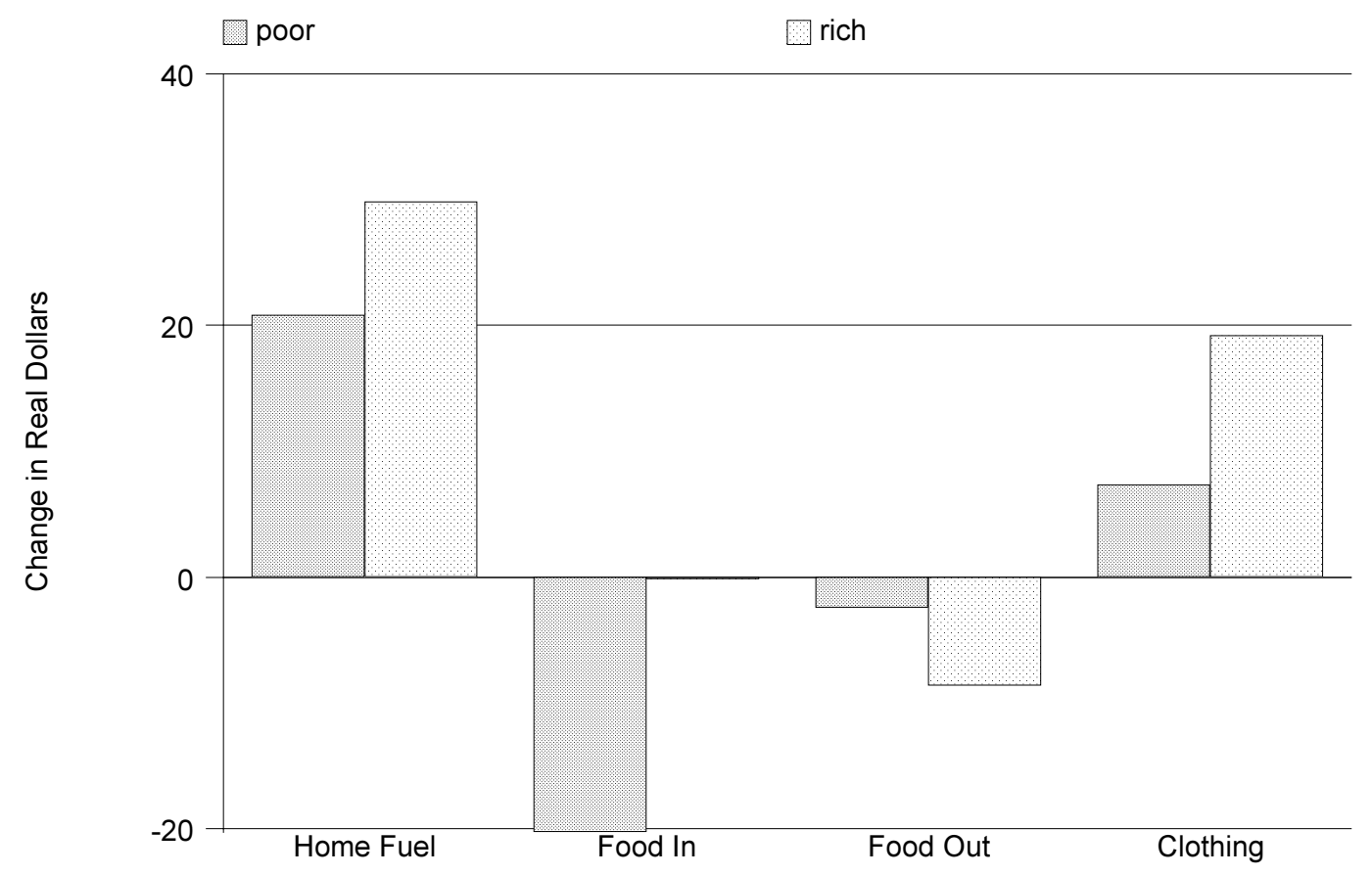

Figure 5b: Results for Lagged Temperature All Regions: State by Year and Month Fixed Effects

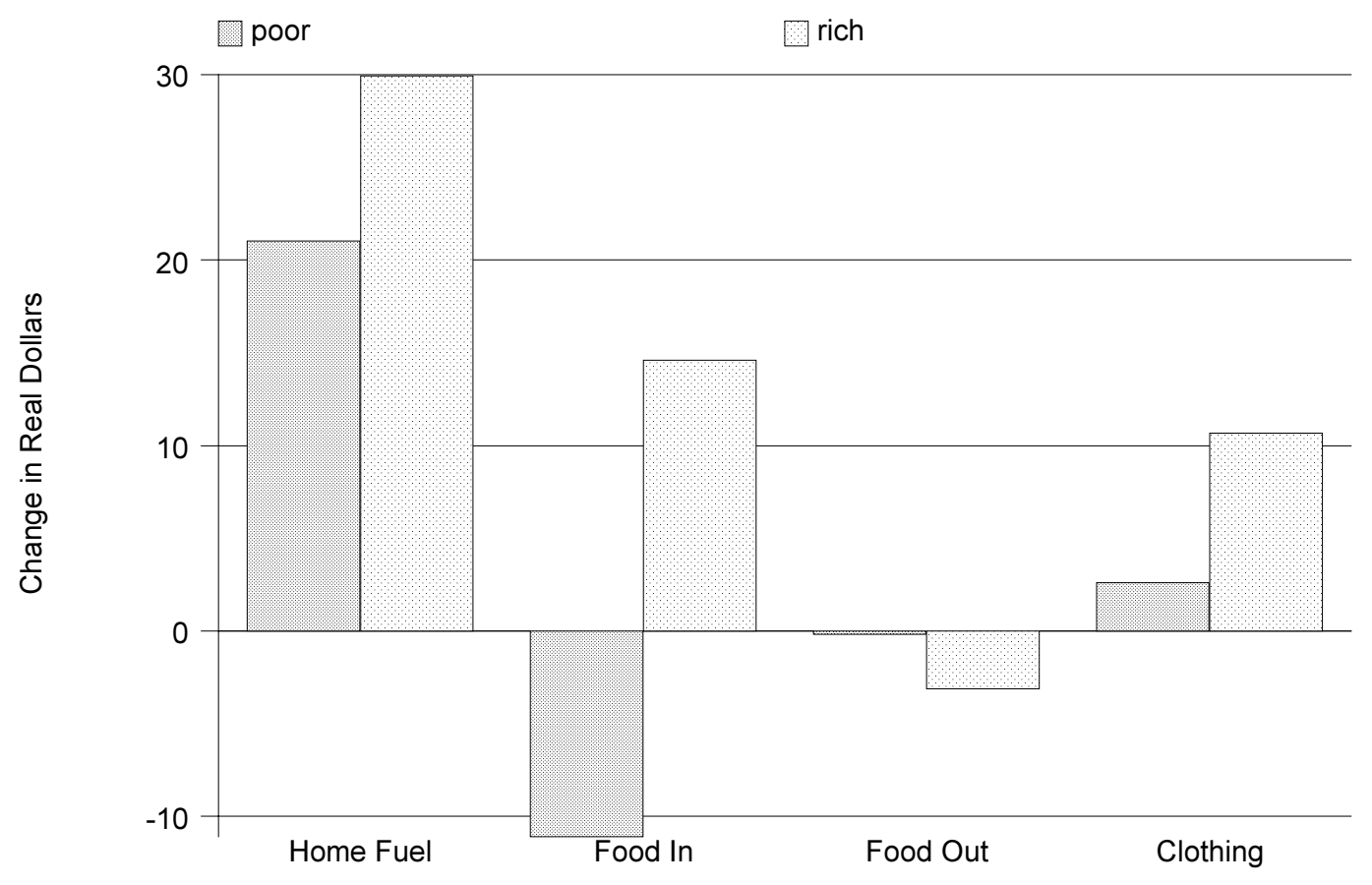


Figure 7a: Results for Preschool Children All Regions: State and Year Fixed Effects

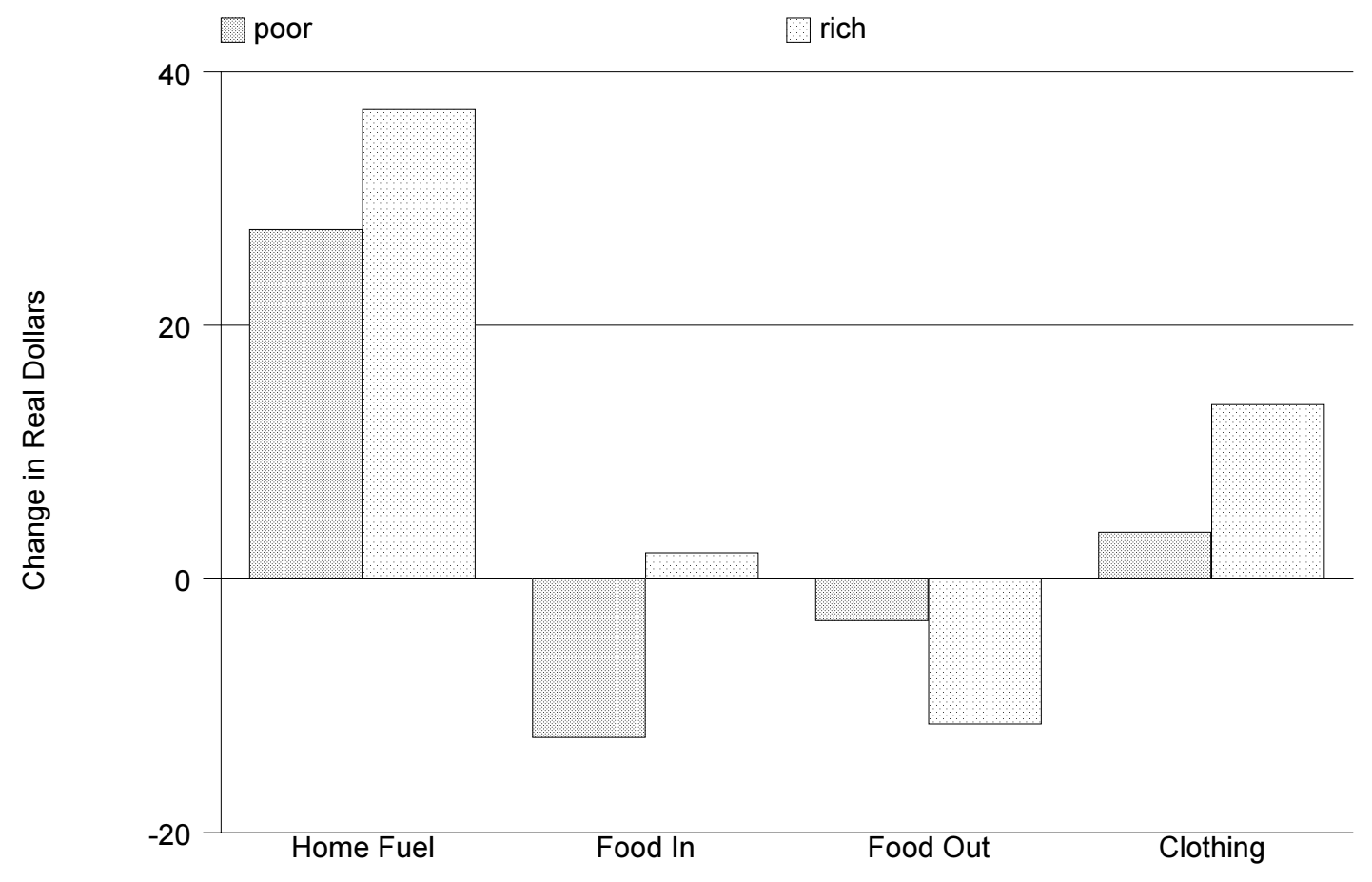

Figure 7b: Results for Preschool Children Lagged Temperature All Regions: State by Year and Month Fixed Effects

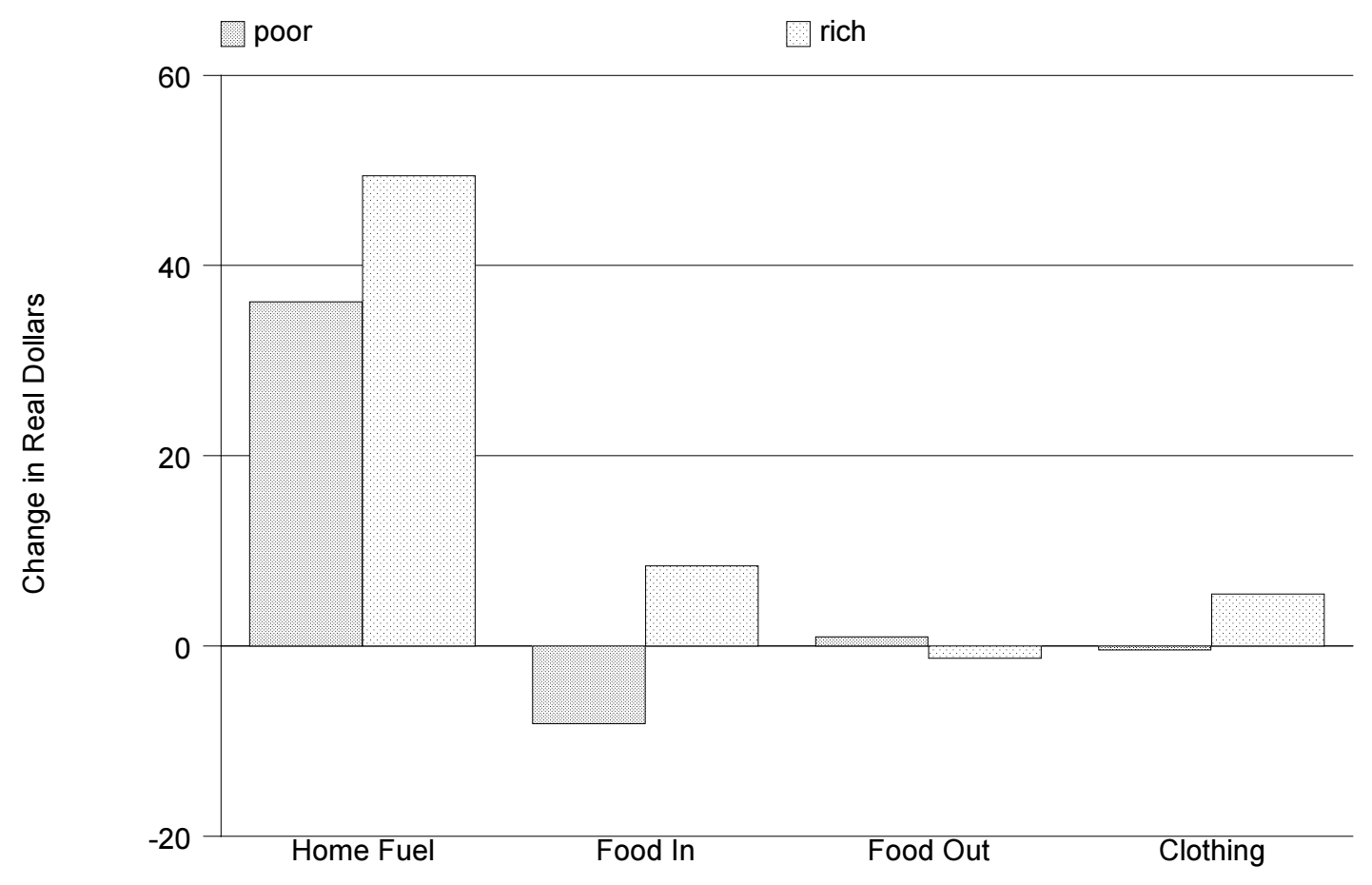




\section{Appendix Table 1a: NHANES Outcomes Regressions for Children (Winter vs. Summer)}

\begin{tabular}{|c|c|c|c|c|}
\hline & Dietary Quality & Anemia & Low $A, C$, or $E$ & Calories \\
\hline \multirow[t]{2}{*}{ Intercept } & 78.44898 & 0.24444 & 0.36851 & 868.59883 \\
\hline & [1.22464] & {$[0.02185]$} & [0.06119] & [70.63783] \\
\hline \multirow[t]{2}{*}{ Winter } & -2.25267 & 0.02426 & 0.00655 & -6.60727 \\
\hline & {$[1.05841]$} & {$[0.02161]$} & {$[0.03390]$} & [71.02870] \\
\hline \multirow[t]{2}{*}{ Poverty-Income Ratio $<1.5$} & -2.90669 & -0.00031587 & 0.04531 & 88.24343 \\
\hline & {$[0.60466]$} & {$[0.01250]$} & [0.01995] & [40.16756] \\
\hline \multirow[t]{2}{*}{ Winter* $(\mathrm{PIR}<1.5)$} & 1.2644 & -0.0033 & 0.03001 & -190.06141 \\
\hline & {$[0.95720]$} & {$[0.01966]$} & {$[0.03097]$} & [64.02962] \\
\hline \multirow[t]{2}{*}{ Age } & -1.34247 & -0.049 & -0.05724 & 97.45716 \\
\hline & {$[0.23026]$} & {$[0.00406]$} & [0.01119] & [12.97140] \\
\hline \multirow[t]{2}{*}{$\operatorname{Age}^{2}$} & 0.0295 & 0.00221 & 0.00224 & -0.79856 \\
\hline & [0.01190] & {$[0.00021803]$} & {$[0.00052117]$} & [0.70559] \\
\hline \multirow[t]{2}{*}{ Non-Hispanic Black } & -1.93289 & 0.08517 & -0.00839 & 32.62531 \\
\hline & {$[0.67045]$} & {$[0.01361]$} & {$[0.02188]$} & [44.62221] \\
\hline \multirow[t]{2}{*}{ Hispanic } & 0.52382 & -0.00781 & -0.04159 & 29.84091 \\
\hline & {$[0.73708]$} & {$[0.01470]$} & {$[0.02423]$} & [48.32086] \\
\hline \multirow[t]{2}{*}{ Male } & 0.52009 & -0.03826 & 0.00704 & 466.15404 \\
\hline & {$[0.44808]$} & {$[0.00916]$} & {$[0.01452]$} & [29.81237] \\
\hline \multirow[t]{2}{*}{ Northeast Region } & -4.84147 & 0.0571 & -0.01449 & 109.71674 \\
\hline & [0.92999] & {$[0.01943]$} & {$[0.03115]$} & [61.90200] \\
\hline \multirow[t]{2}{*}{ Midwest Region } & -2.45418 & 0.02558 & 0.07546 & 126.56446 \\
\hline & {$[0.96461]$} & [0.01953] & [0.03110] & [63.77893] \\
\hline \multirow[t]{2}{*}{ South Region } & -2.80527 & 0.04228 & 0.08333 & -60.93906 \\
\hline & [0.96286] & [0.01974] & [0.03153] & [64.53640] \\
\hline \multirow[t]{2}{*}{ Urban } & -2.4424 & 0.00675 & -0.00254 & 122.06971 \\
\hline & [1.07057] & {$[0.02178]$} & {$[0.03431]$} & [71.34714] \\
\hline \multirow[t]{2}{*}{ Northeast*Urban } & 6.21753 & -0.0055 & 0.00707 & -178.46327 \\
\hline & [1.43356] & [0.02980] & [0.04725] & [95.07697] \\
\hline \multirow[t]{2}{*}{ Midwest*Urban } & 1.73273 & 0.01074 & 0.02847 & -250.82428 \\
\hline & [1.39205] & [0.02815] & [0.04433] & [92.40528] \\
\hline \multirow[t]{2}{*}{ South*Urban } & 3.95284 & -0.00749 & -0.04485 & 146.98465 \\
\hline & [1.33838] & {$[0.02705]$} & {$[0.04277]$} & [89.31249] \\
\hline $\mathrm{R}^{2}$ & 0.1124 & 0.0915 & 0.0506 & 0.2151 \\
\hline
\end{tabular}

Note: The sample for these regressions consists of NHANES households who responded in summer and winter months and who had a PIR $<1.5$ or a PIR $>3.0$. 


\section{Appendix Table 1b: NHANES Outcomes Regressions for Adults with Children (Winter vs. Summer)}

\begin{tabular}{|c|c|c|c|c|}
\hline & Dietary Quality & Anemia & Low $\mathrm{A}, \mathrm{C}$, or $\mathrm{E}$ & Calories \\
\hline \multirow[t]{2}{*}{ Intercept } & 65.75433 & -0.1013 & -0.13673 & 2457.14155 \\
\hline & [3.09897] & {$[0.06014]$} & {$[0.08639]$} & {$[251.78144]$} \\
\hline \multirow[t]{2}{*}{ Winter } & 0.87649 & 0.02102 & 0.06658 & -25.59276 \\
\hline & [1.19374] & {$[0.02358]$} & {$[0.03434]$} & [96.98726] \\
\hline \multirow[t]{2}{*}{ Poverty-Income Ratio $<1.5$} & -4.58202 & 0.01571 & 0.16388 & 73.14429 \\
\hline & {$[0.77651]$} & [0.01539] & {$[0.02204]$} & [63.08898] \\
\hline \multirow[t]{2}{*}{ Winter* $(\operatorname{PIR}<1.5)$} & -0.75364 & -0.00846 & -0.00587 & -215.23236 \\
\hline & [1.16637] & [0.02297] & [0.03317] & {$[94.76376]$} \\
\hline \multirow[t]{2}{*}{ Age } & -0.05997 & 0.00688 & 0.00564 & -18.93863 \\
\hline & [0.14944] & {$[0.00289]$} & {$[0.00416]$} & [12.14120] \\
\hline \multirow[t]{2}{*}{$\mathrm{Age}^{2}$} & 0.00236 & -0.00006935 & -0.00004879 & 0.03344 \\
\hline & {$[0.00191]$} & {$[0.00003677]$} & {$[0.00005285]$} & {$[0.15495]$} \\
\hline \multirow[t]{2}{*}{ Non-Hispanic Black } & -2.61467 & 0.09679 & -0.0708 & 109.7095 \\
\hline & {$[0.87632]$} & {$[0.01734]$} & {$[0.02502]$} & [71.19855] \\
\hline \multirow[t]{2}{*}{ Hispanic } & 3.8704 & 0.02128 & -0.09653 & 83.37496 \\
\hline & {$[0.92461]$} & {$[0.01798]$} & {$[0.02592]$} & [75.12160] \\
\hline \multirow[t]{2}{*}{ Male } & -1.22564 & -0.07879 & 0.00594 & 899.09699 \\
\hline & [0.55289] & {$[0.01086]$} & {$[0.01566]$} & [44.92044] \\
\hline \multirow[t]{2}{*}{ Northeast Region } & -4.68954 & -0.01186 & 0.03223 & 303.18543 \\
\hline & {$[1.17660]$} & {$[0.02303]$} & [0.03309] & [95.59523] \\
\hline \multirow[t]{2}{*}{ Midwest Region } & -2.07107 & 0.03549 & 0.08796 & 51.54706 \\
\hline & [1.24268] & {$[0.02462]$} & {$[0.03514]$} & {$[100.96348]$} \\
\hline \multirow[t]{2}{*}{ South Region } & -4.07721 & 0.03275 & 0.10201 & 50.61006 \\
\hline & [1.21833] & [0.02424] & [0.03553] & [98.98561] \\
\hline \multirow[t]{2}{*}{ Urban } & -6.64195 & 0.00174 & 0.02564 & 163.10875 \\
\hline & [1.24656] & {$[0.02458]$} & [0.03599] & [101.27918] \\
\hline \multirow[t]{2}{*}{ Northeast*Urban } & 12.45891 & 0.07337 & -0.0478 & -474.85327 \\
\hline & [1.68797] & [0.03317] & [0.04835] & [137.14207] \\
\hline \multirow[t]{2}{*}{ Midwest*Urban } & 8.98476 & -0.01101 & 0.01908 & -169.93695 \\
\hline & [1.67505] & [0.03318] & [0.04798] & [136.09222] \\
\hline \multirow[t]{2}{*}{ South*Urban } & 7.62285 & -0.01394 & 0.00647 & -194.97414 \\
\hline & {$[1.59501]$} & [0.03135] & {$[0.04553]$} & [129.58979] \\
\hline $\mathrm{R}^{2}$ & 0.0962 & 0.0711 & 0.0829 & 0.2002 \\
\hline
\end{tabular}

Note: The sample for these regressions consists of NHANES households who responded in summer and winter months and who had a PIR $<1.5$ or a PIR $>3.0$. 


\section{Appendix Table 1c: NHANES Outcomes Regressions for All Adults (Winter vs. Summer)}

\begin{tabular}{lcccc} 
& Dietary Quality & Anemia & Low A, C, or E & Calories \\
\cline { 2 - 5 } Intercept & 64.3689 & 0.03691 & -0.21147 & 2467.92121 \\
& {$[1.56515]$} & {$[0.02957]$} & {$[0.03968]$} & {$[117.46038]$} \\
Winter & 0.58132 & 0.01494 & 0.04303 & -5.72135 \\
& {$[0.82161]$} & {$[0.01563]$} & {$[0.02108]$} & {$[61.65987]$} \\
Poverty-Income Ratio $<1.5$ & -4.53649 & 0.00505 & 0.15467 & 11.71685 \\
& {$[0.52742]$} & {$[0.01008]$} & {$[0.01342]$} & {$[39.58125]$} \\
Winter*(PIR<1.5) & -0.23503 & 0.00060109 & -0.01737 & -141.58457 \\
Age & {$[0.84832]$} & {$[0.01614]$} & {$[0.02152]$} & {$[63.66407]$} \\
& -0.01074 & -0.00054713 & 0.00985 & -14.67841 \\
Age & {$[0.06243]$} & {$[0.00118]$} & {$[0.00158]$} & {$[4.68542]$} \\
& 0.00198 & 0.00001299 & -0.00010489 & -0.00776 \\
Non-Hispanic Black & {$[0.00063673]$} & {$[0.00001201]$} & {$[0.00001610]$} & {$[0.04779]$} \\
Hispanic & -3.96446 & 0.09122 & -0.01528 & -9.08117 \\
& {$[0.64131]$} & {$[0.01226]$} & {$[0.01649]$} & {$[48.12861]$} \\
Male & 1.65758 & 0.00701 & -0.06992 & -51.21137 \\
& {$[0.72592]$} & {$[0.01381]$} & {$[0.01848]$} & {$[54.47870]$} \\
Northeast Region & -3.24459 & -0.04913 & 0.03513 & 848.79972 \\
& {$[0.36991]$} & {$[0.00703]$} & {$[0.00938]$} & {$[27.76115]$} \\
Midwest Region & -0.98518 & 0.00692 & 0.03792 & 43.04681 \\
& {$[0.82062]$} & {$[0.01547]$} & {$[0.02070]$} & {$[61.58556]$} \\
South Region & -0.91411 & 0.01551 & 0.05366 & 72.86628 \\
& {$[0.82548]$} & {$[0.01586]$} & {$[0.02086]$} & {$[61.95017]$} \\
Urban & -2.48755 & 0.02564 & 0.08295 & 9.73671 \\
& {$[0.87675]$} & {$[0.01670]$} & {$[0.02255]$} & {$[65.79830]$} \\
Northeast*Urban & -2.07826 & 0.04226 & 0.08239 & -97.64326 \\
Midwest*Urban & {$[0.92782]$} & {$[0.01760]$} & {$[0.02375]$} & {$[69.63068]$} \\
South*Urban & 4.29763 & 0.0078 & -0.09585 & -16.36218 \\
$\mathrm{R}^{2}$ & {$[1.16376]$} & {$[0.02205]$} & {$[0.02973]$} & {$[87.33768]$} \\
& 4.36679 & -0.04393 & -0.05045 & 49.29778 \\
& {$[1.17342]$} & {$[0.02242]$} & {$[0.02995]$} & {$[88.06238]$} \\
& 3.15321 & -0.01759 & -0.07998 & 108.31043 \\
& {$[1.16165]$} & {$[0.02203]$} & {$[0.02958]$} & {$[87.17925]$} \\
\cline { 2 - 5 } & 0.1151 & 0.0391 & 0.0625 & 0.2272 \\
& & & & \\
& & & &
\end{tabular}

Note: The sample for these regressions consists of NHANES households who responded in summer and winter months and who had a PIR $<1.5$ or a PIR $>3.0$. 


\section{Appendix Table 2a: NHANES Outcomes Regressions for Children (Winter vs. Spring)}

\begin{tabular}{|c|c|c|c|c|}
\hline \multirow{3}{*}{ Intercept } & & & & \\
\hline & 80.50243 & 0.3121 & 0.48192 & 960.21406 \\
\hline & [1.07377] & {$[0.01974]$} & {$[0.05163]$} & [64.62119] \\
\hline \multirow[t]{2}{*}{ Winter } & -2.441 & 0.00749 & -0.03712 & -60.37262 \\
\hline & {$[0.74307]$} & {$[0.01508]$} & {$[0.02379]$} & {$[50.87364]$} \\
\hline \multirow[t]{2}{*}{ Poverty-Income Ratio $<1.5$} & -2.96726 & 0.00342 & 0.05327 & -44.58281 \\
\hline & {$[0.52438]$} & {$[0.01068]$} & {$[0.01727]$} & [35.46800] \\
\hline \multirow[t]{2}{*}{ Winter* $(\mathrm{PIR}<1.5)$} & 1.64462 & -0.00875 & 0.01272 & -84.56922 \\
\hline & {$[0.86267]$} & {$[0.01747]$} & {$[0.02780]$} & {$[58.79276]$} \\
\hline \multirow[t]{2}{*}{ Age } & -1.51484 & -0.05123 & -0.06792 & 110.24338 \\
\hline & {$[0.20177]$} & {$[0.00355]$} & {$[0.00959]$} & [11.68992] \\
\hline \multirow[t]{2}{*}{$\mathrm{Age}^{2}$} & 0.02833 & 0.00235 & 0.00231 & -1.60619 \\
\hline & {$[0.01041]$} & {$[0.00018987]$} & {$[0.00044757]$} & {$[0.63133]$} \\
\hline \multirow[t]{2}{*}{ Non-Hispanic Black } & -1.47136 & 0.08626 & -0.02483 & 43.48662 \\
\hline & {$[0.62453]$} & {$[0.01264]$} & {$[0.02080]$} & [41.90602] \\
\hline \multirow[t]{2}{*}{ Hispanic } & -0.78637 & -0.00866 & -0.00324 & 9.24233 \\
\hline & {$[0.54289]$} & {$[0.01093]$} & {$[0.01782]$} & {$[36.73182]$} \\
\hline \multirow[t]{2}{*}{ Male } & -0.6307 & -0.04126 & 0.01256 & 430.3714 \\
\hline & {$[0.39710]$} & {$[0.00802]$} & {$[0.01300]$} & [26.81809] \\
\hline \multirow[t]{2}{*}{ Northeast Region } & 1.71346 & -0.01576 & -0.09295 & 108.46196 \\
\hline & [1.89106] & [0.04448] & [0.06693] & [125.90259] \\
\hline \multirow[t]{2}{*}{ Midwest Region } & -3.28184 & -0.02884 & -0.03797 & 43.95876 \\
\hline & {$[0.83681]$} & [0.01637] & {$[0.02717]$} & [56.28186] \\
\hline \multirow[t]{2}{*}{ South Region } & -2.82203 & -0.01659 & 0.12282 & -22.57408 \\
\hline & [0.74187] & {$[0.01471]$} & [0.02401] & [50.07453] \\
\hline \multirow[t]{2}{*}{ Urban } & -0.95612 & -0.02698 & 0.01885 & -31.60127 \\
\hline & [0.64419] & [0.01293] & [0.02112] & [43.43743] \\
\hline \multirow[t]{2}{*}{ Northeast*Urban } & - & - & - & - \\
\hline & - & - & - & - \\
\hline \multirow[t]{2}{*}{ Midwest*Urban } & 0.16055 & 0.01564 & 0.11407 & -135.29891 \\
\hline & [1.08024] & [0.02194] & [0.03547] & [72.41517] \\
\hline \multirow[t]{2}{*}{ South*Urban } & 3.05363 & 0.04278 & -0.0753 & 233.57317 \\
\hline & [1.03421] & {$[0.02043]$} & {$[0.03308]$} & [69.92604] \\
\hline$R^{2}$ & 01531 & 00927 & 00891 & 02131 \\
\hline
\end{tabular}

Note: The sample for these regressions consists of NHANES households who responded in spring and winter months and who had a PIR $<1.5$ or a PIR $>3.0$. 


\section{Appendix Table 2b: NHANES Outcomes Regressions for Adults with Children (Winter vs. Spring)}

\begin{tabular}{|c|c|c|c|c|}
\hline & Dietary Quality & Anemia & Low $\mathrm{A}, \mathrm{C}$, or $\mathrm{E}$ & Calories \\
\hline \multirow{2}{*}{ Intercept } & 55.78216 & 0.15004 & -0.05225 & 2064.25313 \\
\hline & {$[2.55443]$} & {$[0.05593]$} & {$[0.08238]$} & {$[210.39888]$} \\
\hline \multirow[t]{2}{*}{ Winter } & -0.96849 & -0.00963 & 0.02216 & 22.78072 \\
\hline & {$[0.81840]$} & {$[0.01758]$} & {$[0.02553]$} & [67.40871] \\
\hline \multirow[t]{2}{*}{ Poverty-Income Ratio $<1.5$} & -2.06953 & -0.00135 & 0.09772 & 80.1145 \\
\hline & {$[0.68551]$} & {$[0.01503]$} & {$[0.02132]$} & {$[56.46301]$} \\
\hline \multirow[t]{2}{*}{ Winter* $(\mathrm{PIR}<1.5)$} & -1.78769 & -0.0053 & 0.04196 & -141.17141 \\
\hline & [1.01729] & {$[0.02194]$} & [0.03149] & [83.79022] \\
\hline \multirow{2}{*}{ Age } & 0.25527 & -0.00117 & 0.00599 & -2.54436 \\
\hline & [0.11936] & {$[0.00261]$} & {$[0.00391]$} & {$[9.83158]$} \\
\hline \multirow[t]{2}{*}{$\mathrm{Age}^{2}$} & -0.00178 & 0.00001725 & -0.0000737 & -0.13557 \\
\hline & {$[0.00146]$} & [0.00003195] & [0.00004849] & {$[0.12027]$} \\
\hline \multirow[t]{2}{*}{ Non-Hispanic Black } & -3.12691 & 0.09789 & -0.04655 & 97.85062 \\
\hline & {$[0.80983]$} & [0.01789] & {$[0.02559]$} & {$[66.70278]$} \\
\hline \multirow[t]{2}{*}{ Hispanic } & 4.02304 & 0.02665 & -0.06349 & -54.20387 \\
\hline & {$[0.70241]$} & {$[0.01516]$} & {$[0.02167]$} & {$[57.85526]$} \\
\hline \multirow[t]{2}{*}{ Male } & 0.43835 & -0.10733 & 0.02941 & 940.62291 \\
\hline & {$[0.49738]$} & {$[0.01078]$} & {$[0.01539]$} & [40.96759] \\
\hline \multirow{2}{*}{ Northeast Region } & -3.38503 & 0.03608 & 0.03706 & -403.42789 \\
\hline & [2.78189] & [0.06047] & [0.08582] & [229.13385] \\
\hline \multirow[t]{2}{*}{ Midwest Region } & 0.14735 & -0.04451 & 0.09042 & 52.09406 \\
\hline & [1.05673] & {$[0.02307]$} & {$[0.03300]$} & [87.03924] \\
\hline \multirow[t]{2}{*}{ South Region } & 0.14189 & -0.01649 & 0.07176 & -15.23304 \\
\hline & [0.92283] & {$[0.02025]$} & [0.02919] & [76.00986] \\
\hline \multirow[t]{2}{*}{ Urban } & 0.39255 & -0.02701 & -0.02185 & 160.24583 \\
\hline & [0.82873] & [0.01815] & [0.02613] & [68.25921] \\
\hline \multirow[t]{2}{*}{ Northeast*Urban } & - & - & - & - \\
\hline & - & - & - & - \\
\hline \multirow[t]{2}{*}{ Midwest*Urban } & -0.77049 & 0.04512 & 0.01974 & -303.49432 \\
\hline & [1.32153] & {$[0.02904]$} & {$[0.04121]$} & [108.84943] \\
\hline \multirow{2}{*}{ South*Urban } & 1.25569 & 0.03205 & 0.05244 & -154.86136 \\
\hline & [1.24209] & [0.02685] & [0.03840] & [102.30595] \\
\hline $\mathrm{R}^{2}$ & 0.0592 & 0.065 & 0.0508 & 0.1993 \\
\hline
\end{tabular}

Note: The sample for these regressions consists of NHANES households who responded in spring and winter months and who had a PIR $<1.5$ or a PIR $>3.0$. 


\section{Appendix Table 2c: NHANES Outcomes Regressions for All Adults (Winter vs. Spring)}

\begin{tabular}{|c|c|c|c|c|}
\hline & Dietary Quality & Anemia & Low $A, C$, or $E$ & Calories \\
\hline \multirow{2}{*}{ Intercept } & 59.50766 & 0.1287 & -0.03798 & 2328.2078 \\
\hline & [1.40736] & {$[0.02776]$} & {$[0.03841]$} & [105.80553] \\
\hline \multirow[t]{2}{*}{ Winter } & -0.311 & 0.03281 & 0.05455 & -90.61667 \\
\hline & {$[0.53605]$} & {$[0.01055]$} & [0.01473] & [40.30062] \\
\hline \multirow[t]{2}{*}{ Poverty-Income Ratio $<1.5$} & -3.06779 & 0.01144 & 0.10173 & -9.38395 \\
\hline & {$[0.47404]$} & {$[0.00933]$} & [0.01289] & {$[35.63857]$} \\
\hline \multirow[t]{2}{*}{ Winter*(PIR<1.5) } & -0.98745 & -0.02404 & 0.0093 & -69.83991 \\
\hline & {$[0.74555]$} & {$[0.01464]$} & {$[0.02034]$} & {$[56.05080]$} \\
\hline \multirow[t]{2}{*}{ Age } & 0.09862 & -0.00254 & 0.00422 & -13.38764 \\
\hline & {$[0.05369]$} & {$[0.00105]$} & {$[0.00145]$} & {$[4.03661]$} \\
\hline \multirow[t]{2}{*}{$\mathrm{Age}^{2}$} & 0.00078449 & 0.00003051 & -0.00005336 & -0.02464 \\
\hline & {$[0.00054206]$} & {$[0.00001060]$} & {$[0.00001467]$} & {$[0.04075]$} \\
\hline \multirow[t]{2}{*}{ Non-Hispanic Black } & -3.932 & 0.10342 & 0.00848 & -34.67683 \\
\hline & [0.61497] & [0.01229] & {$[0.01712]$} & [46.23396] \\
\hline \multirow[t]{2}{*}{ Hispanic } & 2.31862 & 0.02275 & -0.05366 & -82.48201 \\
\hline & {$[0.55711]$} & {$[0.01096]$} & {$[0.01523]$} & {$[41.88358]$} \\
\hline \multirow[t]{2}{*}{ Male } & -1.62608 & -0.07055 & 0.0524 & 848.39848 \\
\hline & {$[0.34004]$} & [0.00669] & {$[0.00925]$} & {$[25.56430]$} \\
\hline \multirow[t]{2}{*}{ Northeast Region } & -4.28351 & -0.01814 & 0.06726 & -433.8681 \\
\hline & {$[1.53178]$} & {$[0.02955]$} & {$[0.04131]$} & [115.15970] \\
\hline \multirow[t]{2}{*}{ Midwest Region } & -1.92209 & -0.01637 & 0.08351 & 165.47382 \\
\hline & [0.75429] & {$[0.01500]$} & [0.02087] & [56.70773] \\
\hline \multirow[t]{2}{*}{ South Region } & -0.51255 & -0.0197 & 0.04021 & 179.43836 \\
\hline & [0.69860] & [0.01389] & {$[0.01937]$} & [52.52102] \\
\hline \multirow[t]{2}{*}{ Urban } & 1.59195 & -0.02164 & -0.00653 & 181.71733 \\
\hline & [0.64582] & {$[0.01288]$} & [0.01794] & [48.55321] \\
\hline \multirow[t]{2}{*}{ Northeast*Urban } & - & - & - & - \\
\hline & - & - & - & - \\
\hline \multirow[t]{2}{*}{ Midwest*Urban } & -0.08658 & 0.06208 & 0.01234 & -359.38587 \\
\hline & [0.93119] & {$[0.01860]$} & {$[0.02561]$} & [70.00721] \\
\hline \multirow[t]{2}{*}{ South*Urban } & -0.13772 & 0.04377 & -0.00634 & -148.44308 \\
\hline & [0.94483] & {$[0.01867]$} & {$[0.02590]$} & [71.03283] \\
\hline K & 0.1075 & 0.0458 & 0.0491 & 0.2388 \\
\hline
\end{tabular}

Note: The sample for these regressions consists of NHANES households who responded in spring and winter months and who had a PIR $<1.5$ or a PIR $>3.0$. 


\section{Appendix Table 3a: NHANES Outcomes Regressions for Children (Winter vs. Fall)}

\begin{tabular}{|c|c|c|c|c|}
\hline & Dietary Quality & Anemia & Low $\mathrm{A}, \mathrm{C}$, or $\mathrm{E}$ & Calories \\
\hline \multirow[t]{2}{*}{ Intercept } & 77.27947 & 0.18515 & 0.38798 & 927.54078 \\
\hline & [1.48097] & {$[0.02844]$} & {$[0.06287]$} & {$[93.06765]$} \\
\hline \multirow[t]{2}{*}{ Winter } & -2.02445 & 0.06201 & -0.00136 & 94.15251 \\
\hline & {$[0.73736]$} & {$[0.01524]$} & [0.02417] & [50.20979] \\
\hline \multirow[t]{2}{*}{ Poverty-Income Ratio $<1.5$} & -3.67666 & 0.03991 & 0.03426 & -16.59941 \\
\hline & [0.53249] & {$[0.01096]$} & {$[0.01780]$} & {$[35.67354]$} \\
\hline \multirow[t]{2}{*}{ Winter* $(\mathrm{PIR}<1.5)$} & 2.14923 & -0.04324 & 0.02397 & -55.23207 \\
\hline & {$[0.86276]$} & {$[0.01777]$} & {$[0.02877]$} & {$[58.29154]$} \\
\hline \multirow[t]{2}{*}{ Age } & -1.33206 & -0.04169 & -0.05591 & 110.9079 \\
\hline & [0.20132] & {$[0.00352]$} & {$[0.00988]$} & [11.24479] \\
\hline \multirow[t]{2}{*}{$\mathrm{Age}^{2}$} & 0.03097 & 0.00176 & 0.00173 & -1.94114 \\
\hline & {$[0.01040]$} & {$[0.00018861]$} & [0.00045969] & [0.61413] \\
\hline \multirow[t]{2}{*}{ Non-Hispanic Black } & -0.8228 & 0.08594 & 0.01806 & 16.30151 \\
\hline & {$[0.54254]$} & {$[0.01114]$} & {$[0.01850]$} & {$[36.20957]$} \\
\hline \multirow[t]{2}{*}{ Hispanic } & -0.41039 & -0.00493 & 0.00136 & -144.92418 \\
\hline & {$[0.59247]$} & {$[0.01200]$} & {$[0.01980]$} & [39.61034] \\
\hline \multirow[t]{2}{*}{ Male } & 0.7876 & -0.01479 & 0.02304 & 476.30899 \\
\hline & {$[0.39570]$} & {$[0.00807]$} & [0.01323] & [26.44353] \\
\hline \multirow[t]{2}{*}{ Northeast Region } & 3.01342 & 0.05755 & 0.03081 & 331.76177 \\
\hline & {$[1.38738]$} & {$[0.02824]$} & {$[0.04566]$} & [94.11513] \\
\hline \multirow[t]{2}{*}{ Midwest Region } & 0.04286 & -0.01124 & 0.12312 & 248.15061 \\
\hline & [1.80474] & {$[0.03620]$} & {$[0.05857]$} & [119.93513] \\
\hline \multirow[t]{2}{*}{ South Region } & -2.06067 & 0.02937 & 0.10178 & -125.51424 \\
\hline & [1.16221] & {$[0.02370]$} & [0.03889] & [78.85333] \\
\hline \multirow[t]{2}{*}{ Urban } & -2.01841 & -0.00344 & 0.03034 & -65.83996 \\
\hline & [1.25248] & {$[0.02587]$} & [0.04245] & [84.73660] \\
\hline \multirow[t]{2}{*}{ Northeast*Urban } & 0.78854 & -0.02278 & -0.04746 & -206.63707 \\
\hline & {$[1.56431]$} & {$[0.03215]$} & {$[0.05210]$} & [105.94900] \\
\hline \multirow[t]{2}{*}{ Midwest*Urban } & - & -0.2416 & - & -265.82928 \\
\hline & - & [0.41685] & - & [1453.94105] \\
\hline \multirow[t]{2}{*}{ South*Urban } & 3.30964 & 0.00609 & -0.06269 & 154.69064 \\
\hline & [1.35950] & {$[0.02806]$} & {$[0.04608]$} & {$[91.77206]$} \\
\hline $\mathrm{R}^{2}$ & 0.1244 & 0.0987 & 0.0792 & 0.2217 \\
\hline
\end{tabular}

Note: The sample for these regressions consists of NHANES households who responded in fall and winter months and who had a PIR $<1.5$ or a PIR $>3.0$. 


\section{Appendix Table 3b: NHANES Outcomes Regressions for Adults with Children (Winter vs. Fall)}

\begin{tabular}{|c|c|c|c|c|}
\hline & Dietary Quality & Anemia & Low $\mathrm{A}, \mathrm{C}$, or $\mathrm{E}$ & Calories \\
\hline \multirow[t]{2}{*}{ Intercept } & 59.34716 & 0.04914 & -0.18883 & 2652.79073 \\
\hline & {$[2.79760]$} & {$[0.06047]$} & {$[0.08853]$} & [226.06393] \\
\hline \multirow[t]{2}{*}{ Winter } & 0.45739 & -0.00346 & 0.03679 & -236.66913 \\
\hline & {$[0.87833]$} & [0.01884] & [0.02716] & {$[70.97458]$} \\
\hline \multirow[t]{2}{*}{ Poverty-Income Ratio $<1.5$} & -4.92444 & -0.00134 & 0.12032 & -233.68743 \\
\hline & {$[0.70871]$} & {$[0.01522]$} & [0.02199] & {$[57.26846]$} \\
\hline \multirow[t]{2}{*}{ Winter* $(\mathrm{PIR}<1.5)$} & -0.04941 & -0.004 & 0.00194 & 141.10986 \\
\hline & {$[1.08163]$} & {$[0.02308]$} & [0.03343] & [87.40289] \\
\hline \multirow[t]{2}{*}{ Age } & 0.14122 & 0.00153 & 0.00551 & -24.79192 \\
\hline & {$[0.11470]$} & {$[0.00251]$} & {$[0.00362]$} & [9.26885] \\
\hline \multirow[t]{2}{*}{$\mathrm{Age}^{2}$} & -0.00088161 & -0.00001203 & -0.00003883 & 0.10965 \\
\hline & [0.00139] & [0.00003073] & [0.00004435] & [0.11232] \\
\hline \multirow[t]{2}{*}{ Non-Hispanic Black } & -1.3272 & 0.10655 & -0.01887 & -49.00072 \\
\hline & {$[0.72832]$} & {$[0.01572]$} & {$[0.02276]$} & {$[58.85261]$} \\
\hline \multirow[t]{2}{*}{ Hispanic } & 3.68863 & 0.02855 & 0.00975 & -4.08347 \\
\hline & {$[0.81311]$} & {$[0.01711]$} & {$[0.02485]$} & {$[65.70419]$} \\
\hline \multirow[t]{2}{*}{ Male } & -0.97203 & -0.10354 & 0.0669 & 886.88117 \\
\hline & {$[0.50675]$} & {$[0.01086]$} & {$[0.01570]$} & {$[40.94898]$} \\
\hline \multirow[t]{2}{*}{ Northeast Region } & 3.02258 & -0.03463 & 0.07787 & -261.50166 \\
\hline & {$[1.79372]$} & {$[0.03901]$} & {$[0.05815]$} & [144.94428] \\
\hline \multirow[t]{2}{*}{ Midwest Region } & 8.02317 & -0.0705 & 0.02436 & -20.56397 \\
\hline & [2.50387] & [0.05368] & [0.07894] & [202.32848] \\
\hline \multirow[t]{2}{*}{ South Region } & -0.22974 & 0.03248 & 0.16913 & 241.53642 \\
\hline & [1.52145] & {$[0.03306]$} & {$[0.05005]$} & [122.94321] \\
\hline \multirow[t]{2}{*}{ Urban } & -2.10537 & 0.00465 & 0.05816 & 291.29772 \\
\hline & [1.62695] & {$[0.03523]$} & {$[0.05322]$} & [131.46798] \\
\hline \multirow[t]{2}{*}{ Northeast*Urban } & 4.64188 & 0.02534 & -0.10837 & 237.29053 \\
\hline & [2.01211] & [0.04356] & {$[0.06478]$} & [162.59128] \\
\hline \multirow[t]{2}{*}{ Midwest*Urban } & - & - & - & - \\
\hline & - & - & - & - \\
\hline \multirow[t]{2}{*}{ South*Urban } & 2.88356 & -0.01678 & -0.10291 & -357.65251 \\
\hline & {$[1.75516]$} & {$[0.03800]$} & {$[0.05711]$} & [141.82847] \\
\hline $\mathrm{R}^{2}$ & 0.0917 & 0.0762 & 0.0599 & 0.207 \\
\hline
\end{tabular}

Note: The sample for these regressions consists of NHANES households who responded in fall and winter months and who had a PIR $<1.5$ or a PIR $>3.0$. 


\section{Appendix Table 3c: NHANES Outcomes Regressions for All Adults (Winter vs.}

Fall)

\begin{tabular}{|c|c|c|c|c|}
\hline & Dietary Quality & Anemia & Low $\mathrm{A}, \mathrm{C}$, or $\mathrm{E}$ & Calories \\
\hline \multirow[t]{2}{*}{ Intercept } & 63.73906 & 0.08044 & -0.08489 & 2385.07019 \\
\hline & [1.80775] & {$[0.03605]$} & {$[0.05167]$} & [136.44166] \\
\hline \multirow[t]{2}{*}{ Winter } & 0.4462 & 0.01644 & 0.0045 & -81.0086 \\
\hline & {$[0.56366]$} & [0.01123] & {$[0.01586]$} & [42.54250] \\
\hline \multirow[t]{2}{*}{ Poverty-Income Ratio $<1.5$} & -5.45358 & 0.01292 & 0.10418 & -187.8382 \\
\hline & {$[0.48167]$} & {$[0.00960]$} & [0.01359] & [36.35462] \\
\hline \multirow[t]{2}{*}{ Winter*(PIR<1.5) } & 0.55572 & -0.01754 & 0.01266 & 83.90234 \\
\hline & {$[0.78214]$} & {$[0.01554]$} & [0.02199] & [59.03297] \\
\hline \multirow[t]{2}{*}{ Age } & -0.05774 & -0.00155 & 0.0034 & -18.40713 \\
\hline & {$[0.05780]$} & {$[0.00115]$} & {$[0.00163]$} & {$[4.36273]$} \\
\hline \multirow[t]{2}{*}{$\mathrm{Age}^{2}$} & 0.00196 & 0.00002455 & -0.00004404 & 0.02129 \\
\hline & [0.00059104] & {$[0.00001173]$} & {$[0.00001666]$} & {$[0.04461]$} \\
\hline \multirow[t]{2}{*}{ Non-Hispanic Black } & -2.57179 & 0.11165 & 0.00058325 & -69.12638 \\
\hline & [0.54439] & [0.01095] & {$[0.01554]$} & [41.08814] \\
\hline \multirow[t]{2}{*}{ Hispanic } & 2.12422 & 0.01889 & -0.01621 & -67.1783 \\
\hline & {$[0.62551]$} & {$[0.01234]$} & {$[0.01756]$} & [47.21070] \\
\hline \multirow[t]{2}{*}{ Male } & -2.42654 & -0.06967 & 0.07832 & 847.59421 \\
\hline & [0.35093] & [0.00699] & {$[0.00988]$} & [26.48703] \\
\hline \multirow[t]{2}{*}{ Northeast Region } & 2.07342 & -0.02658 & 0.10252 & -42.78635 \\
\hline & {$[1.39143]$} & {$[0.02780]$} & {$[0.04007]$} & {$[105.01975]$} \\
\hline \multirow[t]{2}{*}{ Midwest Region } & 3.54684 & -0.03912 & 0.10611 & 106.3765 \\
\hline & [1.68314] & {$[0.03350]$} & [0.04823] & [127.03655] \\
\hline \multirow[t]{2}{*}{ South Region } & -0.25782 & 0.01473 & 0.14346 & 294.52914 \\
\hline & [1.20767] & {$[0.02416]$} & {$[0.03507]$} & [91.14976] \\
\hline \multirow[t]{2}{*}{ Urban } & 0.47171 & 0.02881 & 0.11364 & 161.90501 \\
\hline & [1.28330] & {$[0.02570]$} & {$[0.03724]$} & [96.85793] \\
\hline \multirow[t]{2}{*}{ Northeast*Urban } & 1.98891 & 0.00804 & -0.20404 & 344.30394 \\
\hline & {$[1.53610]$} & [0.03069] & [0.04416] & [1 115.93826$]$ \\
\hline \multirow[t]{2}{*}{ Midwest*Urban } & - & - & - & - \\
\hline & - & - & - & - \\
\hline \multirow[t]{2}{*}{ South*Urban } & 0.82808 & -0.02428 & -0.15441 & -147.48128 \\
\hline & [1.35788] & {$[0.02718]$} & {$[0.03929]$} & {$[102.48717]$} \\
\hline $\mathrm{R}^{2}$ & 0.096 & 0.0524 & 0.0469 & 0.2394 \\
\hline
\end{tabular}

Note: The sample for these regressions consists of NHANES households who responded in fall and winter months and who had a PIR $<1.5$ or a PIR $>3.0$. 


\section{Appendix Table 4a: Winter vs. Summer NHANES Outcomes Regressions for Children (Excluding Southern Households)}

\begin{tabular}{|c|c|c|c|c|}
\hline & Dietary Quality & Anemia & Low $A, C$, or $E$ & Calories \\
\hline \multirow{2}{*}{ Intercept } & 78.33519 & 0.23802 & 0.34544 & 867.82467 \\
\hline & {$[1.50238]$} & {$[0.02493]$} & {$[0.07502]$} & {$[80.51615]$} \\
\hline \multirow[t]{2}{*}{ Winter } & -3.91234 & 0.03494 & -0.00261 & -101.55793 \\
\hline & [1.61974] & {$[0.03084]$} & {$[0.04915]$} & {$[102.45931]$} \\
\hline \multirow[t]{2}{*}{ Poverty-Income Ratio $<1.5$} & -2.3164 & 0.00476 & 0.03849 & 104.82842 \\
\hline & {$[0.69480]$} & {$[0.01353]$} & {$[0.02187]$} & [43.61265] \\
\hline \multirow[t]{2}{*}{ Winter*(PIR $<1.5)$} & 1.34453 & -0.01282 & 0.0623 & -191.04099 \\
\hline & [1.56949] & {$[0.03070]$} & {$[0.04967]$} & [99.00513] \\
\hline \multirow[t]{2}{*}{ Age } & -1.25422 & -0.0498 & -0.05314 & 86.88435 \\
\hline & [0.29224] & {$[0.00489]$} & [0.01399] & {$[15.49051]$} \\
\hline \multirow[t]{2}{*}{$\mathrm{Age}^{2}$} & 0.0263 & 0.00225 & 0.00208 & 0.17089 \\
\hline & {$[0.01510]$} & {$[0.00026395]$} & {$[0.00065078]$} & {$[0.84431]$} \\
\hline \multirow[t]{2}{*}{ Non-Hispanic Black } & -3.7208 & 0.08037 & 0.03657 & 6.98608 \\
\hline & {$[0.94115]$} & {$[0.01805]$} & [0.02947] & [59.18857] \\
\hline \multirow[t]{2}{*}{ Hispanic } & 0.0308 & 0.00589 & -0.03604 & 80.9396 \\
\hline & {$[1.02734]$} & {$[0.01923]$} & {$[0.03278]$} & [62.84234] \\
\hline \multirow[t]{2}{*}{ Male } & 0.51767 & -0.03066 & -0.00571 & 489.01053 \\
\hline & {$[0.57519]$} & {$[0.01114]$} & {$[0.01804]$} & [36.08447] \\
\hline \multirow[t]{2}{*}{ Northeast Region } & -5.4969 & 0.05966 & -0.00633 & 74.51475 \\
\hline & {$[1.04957]$} & {$[0.02059]$} & {$[0.03353]$} & {$[65.96770]$} \\
\hline \multirow[t]{2}{*}{ Midwest Region } & -2.94315 & 0.02883 & 0.07767 & 105.05968 \\
\hline & {$[1.08578]$} & {$[0.02065]$} & [0.03347] & [67.78372] \\
\hline \multirow[t]{2}{*}{ Urban } & -1.41864 & 0.00265 & -0.00103 & 177.18026 \\
\hline & [1.29495] & {$[0.02451]$} & [0.03925] & [81.24793] \\
\hline \multirow[t]{2}{*}{ Northeast*Urban } & 5.64942 & -0.00424 & -0.00061495 & -229.77602 \\
\hline & [1.68403] & {$[0.03257]$} & {$[0.05232]$} & [105.21927] \\
\hline \multirow[t]{2}{*}{ Midwest*Urban } & 1.0855 & 0.01505 & 0.02016 & -305.48989 \\
\hline & [1.63480] & {$[0.03084]$} & [0.04938] & [102.37101] \\
\hline $\mathrm{R}^{2}$ & 0.1172 & 0.1018 & 0.0542 & 0.2487 \\
\hline
\end{tabular}

Note: The sample for these regressions consists of NHANES households who responded in summer and winter months and who had a PIR $<1.5$ or a PIR $>3.0$. It excludes southern households. 


\section{Appendix Table 4b: Winter vs. Summer NHANES Outcomes Regressions for Adults with Children (Excluding Southern Households)}

\begin{tabular}{lcccc} 
& Dietary Quality & Anemia & Low A, C, or E & Calories \\
\cline { 2 - 5 } Intercept & 71.48488 & -0.05569 & -0.16493 & 2469.41773 \\
& {$[4.00111]$} & {$[0.07164]$} & {$[0.09998]$} & {$[331.42033]$} \\
Winter & -0.21866 & 0.0306 & 0.12023 & -61.68929 \\
& {$[1.68059]$} & {$[0.03086]$} & {$[0.04403]$} & {$[139.20660]$} \\
Poverty-Income Ratio $<1.5$ & -4.53794 & 0.00859 & 0.13995 & 101.49048 \\
& {$[0.89444]$} & {$[0.01650]$} & {$[0.02298]$} & {$[74.08818]$} \\
Winter*(PIR<1.5) & -0.96592 & 0.00404 & -0.07602 & -311.81809 \\
& {$[1.92861]$} & {$[0.03562]$} & {$[0.05116]$} & {$[159.75077]$} \\
Age & -0.30228 & 0.00424 & 0.00683 & -17.47384 \\
& {$[0.19634]$} & {$[0.00348]$} & {$[0.00486]$} & {$[16.26317]$} \\
Age & 0.00528 & $-3.9 \mathrm{E}-05$ & -0.00005906 & 0.01735 \\
& {$[0.00251]$} & {$[0.00004408]$} & {$[0.00006154]$} & {$[0.20770]$} \\
Non-Hispanic Black & -4.5348 & 0.10166 & -0.00807 & 72.44221 \\
& {$[1.23706]$} & {$[0.02293]$} & {$[0.03222]$} & {$[102.46784]$} \\
Hispanic & 2.72044 & 0.0058 & -0.08418 & -34.52193 \\
& {$[1.32445]$} & {$[0.02411]$} & {$[0.03407]$} & {$[109.70673]$} \\
Male & -1.81212 & -0.06335 & 0.00413 & 912.97522 \\
& {$[0.70944]$} & {$[0.01303]$} & {$[0.01829]$} & {$[58.76420]$} \\
Northeast Region & -5.45039 & -0.00907 & 0.04178 & 248.76145 \\
& {$[1.32555]$} & {$[0.02414]$} & {$[0.03366]$} & {$[109.79789]$} \\
Midwest Region & -2.73185 & 0.04011 & 0.09412 & -5.88635 \\
& {$[1.39533]$} & {$[0.02571]$} & {$[0.03563]$} & {$[115.57821]$} \\
Urban & -6.24094 & -0.00535 & 0.00626 & 181.62168 \\
& {$[1.45344]$} & {$[0.02676]$} & {$[0.03799]$} & {$[120.39168]$} \\
Northeast*Urban & 12.52241 & 0.08317 & -0.04062 & -469.2031 \\
& {$[1.93808]$} & {$[0.03554]$} & {$[0.05039]$} & {$[160.53499]$} \\
Midwest*Urban & 8.98862 & -0.00475 & 0.02782 & -171.07401 \\
$\mathrm{R}^{2}$ & {$[1.91774]$} & {$[0.03542]$} & {$[0.04983]$} & {$[158.85048]$} \\
& 0.103 & 0.0684 & 0.0684 & 0.2026 \\
& & & &
\end{tabular}

Note: The sample for these regressions consists of NHANES households who responded in summer and winter months and who had a PIR $<1.5$ or a PIR $>3.0$. It excludes southern households. 


\section{Appendix Table 4c: Winter vs. Summer NHANES Outcomes Regressions for All Adults (Excluding Southern Households)}

\begin{tabular}{lcccc} 
& Dietary Quality & Anemia & Low A, C, or E & Calories \\
\cline { 2 - 5 } Intercept & 64.20584 & 0.08698 & -0.20732 & 2467.99225 \\
& {$[2.51519]$} & {$[0.04486]$} & {$[0.05874]$} & {$[176.25689]$} \\
Winter & -1.93877 & 0.023 & 0.03247 & -248.41575 \\
& {$[1.77288]$} & {$[0.03142]$} & {$[0.04099]$} & {$[124.23843]$} \\
Poverty-Income Ratio $<1.5$ & -4.47286 & -0.01386 & 0.14415 & -30.95028 \\
& {$[0.83030]$} & {$[0.01485]$} & {$[0.01920]$} & {$[58.18478]$} \\
Winter*(PIR $<1.5)$ & 2.93831 & 0.00885 & -0.13743 & -50.2613 \\
& {$[2.39088]$} & {$[0.04353]$} & {$[0.05577]$} & {$[167.54559]$} \\
Age & 0.00000609 & -0.00285 & 0.01013 & -10.93942 \\
& {$[0.10009]$} & {$[0.00178]$} & {$[0.00233]$} & {$[7.01376]$} \\
Age ${ }^{2}$ & 0.00179 & $3.24 \mathrm{E}-05$ & -0.00010644 & -0.03669 \\
& {$[0.00101]$} & {$[0.00001794]$} & {$[0.00002341]$} & {$[0.07086]$} \\
Non-Hispanic Black & -5.15545 & 0.09443 & 0.03863 & -88.06676 \\
& {$[1.33101]$} & {$[0.02386]$} & {$[0.03133]$} & {$[93.27349]$} \\
Hispanic & -2.04029 & -0.018 & -0.05789 & -226.42354 \\
& {$[1.50568]$} & {$[0.02739]$} & {$[0.03581]$} & {$[105.51364]$} \\
Male & -4.40516 & -0.03472 & 0.05842 & 848.35523 \\
& {$[0.61878]$} & {$[0.01104]$} & {$[0.01426]$} & {$[43.36243]$} \\
Northeast Region & 1.30496 & 0.02568 & 0.02568 & -171.83826 \\
& {$[1.26270]$} & {$[0.02231]$} & {$[0.02898]$} & {$[88.48658]$} \\
Midwest Region & -0.12396 & 0.01387 & 0.02184 & 11.95257 \\
& {$[1.24536]$} & {$[0.02249]$} & {$[0.02860]$} & {$[87.27136]$} \\
Urban & 2.83248 & 0.06853 & 0.11468 & -133.22856 \\
& {$[1.65881]$} & {$[0.02936]$} & {$[0.03831]$} & {$[116.24435]$} \\
Northeast*Urban & -2.37769 & -0.03432 & -0.13103 & 142.6764 \\
Midwest*Urban & {$[1.95107]$} & {$[0.03453]$} & {$[0.04509]$} & {$[136.72561]$} \\
$\mathrm{R}^{2}$ & -0.65116 & -0.07491 & -0.09712 & 65.98162 \\
& {$[1.97279]$} & {$[0.03522]$} & {$[0.04560]$} & {$[138.24728]$} \\
\cline { 2 - 5 } & 0.1182 & 0.034 & 0.0647 & 0.2693 \\
& & & &
\end{tabular}

Note: The sample for these regressions consists of NHANES households who responded in summer and winter months and who had a PIR $<1.5$ or a PIR $>3.0$. It excludes southern households. 
Appendix Table 5. Laboratory Cutoffs for Serum Measures ${ }^{\mathrm{a}}$

\begin{tabular}{lll}
\hline Condition & Ages/Gender & Criteria \\
\hline Anemia & $0-11$ & hemoglobin $<11.5 \mathrm{~g} / \mathrm{dL}$ and hematocrit $<35 \%$ \\
& $12-17$ & hemoglobin $<12 \mathrm{~g} / \mathrm{dL}$ and hematocrit $<37 \%$ \\
& $>18 /$ Female & hemoglobin $<12 \mathrm{~g} / \mathrm{dL}$ and hematocrit $<36 \%$ \\
& $>18 /$ Male & hemoglobin $<13 \mathrm{~g} / \mathrm{dL}$ and hematocrit $<39 \%$ \\
& & $<11.4 \mathrm{mmol} / \mathrm{L}$ \\
Short Vitamin C & $<1.05 \mu \mathrm{mol} / \mathrm{L}$ \\
Short Vitamin A & & $<11.6 \mu \mathrm{mol} / \mathrm{L}$ \\
Short Vitamin E &
\end{tabular}

a Sources: Wilson et al. (1991) and DeAngelis et al. (1999) 